\title{
Monitoring climatological, hydrological and geochemical parameters in the Père Noël cave (Belgium): implication for the interpretation of speleothem isotopic and geochemical time-series
}

\author{
Sophie Verheyden ${ }^{1,2}$, Dominique Genty ${ }^{3}$, Guy Deflandre ${ }^{4}$, Yves Quinif ${ }^{5}$ and Eduard Keppens ${ }^{1}$
}

\begin{abstract}
:
Verheyden S., Genty D., Deflandre G., Quinif Y. and Keppens E. 2008. Monitoring climatological, hydrological and geochemical parameters in the Père Noël cave (Belgium): implication for the interpretation of speleothem isotopic and geochemical time-series. International Journal of Speleology, 37 (3), 221-234. Bologna (Italy). ISSN 0392-6672.

Père Noël cave climatology (air and water temperature, $\mathrm{P}_{\mathrm{CO} 2}$ ), hydrology (drip rate, conductivity) and geochemistry of water and calcite deposits $\left(\delta^{18} \mathrm{O}, \boldsymbol{\delta}^{13} \mathrm{C}, \mathrm{Mg} / \mathrm{Ca}\right.$ and $\left.\mathrm{Sr} / \mathrm{Ca}\right)$ where studied to better interpret stable isotopic and trace element variations of speleothems. Results of an automated monitoring station and of manual sampling between 1991 and 1998 have demonstrated the highly seasonal signal of drip rate, its control by water excess and rainfall, and, at a shorter scale to air pressure changes.

The modern calcite deposit study suggests a relationship between cave calcite isotopic composition $\left(\delta^{18} \mathrm{O}\right.$ and $\left.\boldsymbol{\delta}^{13} \mathrm{C}\right)$ and drip rate likely due to variations in degree of isotopic equilibrium during calcite precipitation. $\delta^{18} \mathrm{O}$ and $\boldsymbol{\delta}^{13} \mathrm{C}$ of the calcite are therefore, through drip rate, linked to water recharge. $\mathrm{Mg} / \mathrm{Ca}$ and $\mathrm{Sr} / \mathrm{Ca}$ ratios of Père Noël cave calcite, depend closely on the residence time of the water, and therefore are also linked to drip rate and therefore to water recharge. This crossed link of $\delta^{18} \mathrm{O}$ and $\boldsymbol{\delta}^{13} \mathrm{C}$ as of $\mathrm{Mg} / \mathrm{Ca}$ and $\mathrm{Sr} / \mathrm{Ca}$ to water recharge may explain the very similar variations of these four parameters along the longitudinal axis of a Holocene stalagmite, but it may also be the consequence of kinetic effects during calcite precipitation as suggested by similar variations of the four parameters along a single layer of the Holocene stalagmite.
\end{abstract}

Keywords: cave hydrology, isotopes (oxygen and carbon), palaeoclimatology, drip rate, monitoring, modern calcite, seepage water, $\mathrm{Mg}, \mathrm{Sr}$

Received 7 October 2008; Revised 21 October 2008; Accepted 22 October 2008

\section{INTRODUCTION}

The Père Noël cave was discovered in 1964 during Christmas time (hence the cave's name) by a group of cavers among which Guy Deflandre. It is part of the karstic system which encloses the well-known Belgian caves of Han-sur-Lesse (Quinif \& Bastin, 1986; Deflandre et al., 1987).

A first automatic monitoring device was installed in the Père Noël cave in 1991, seepage water was then monitored until 1999. First results of seepage water driprate, flowrate and conductivity were published in Genty \& Deflandre (1998). Here, we first recall the main results obtained thanks to this monitoring, then we present additional information on the oxygen

1 Vrije Universiteit Brussel (VUB) Dep. of Geology Pleinlaan 2, B-1050 Brussels. verheydensophie@gmail.com

2 Present address: DSTE 160/02 Université Libre de Bruxelles, Av F.D. Roosevelt, 50, 1050 Bruxelles, Belgium

3 Laboratoire des sciences du climat et de l'environnement. UMR CEA/CNRS/UVSQ 1572 Bât 709, L'Orme des Merisiers CEA Saclay, 91191 Gif sur Yvette Cedex France.

dominique.genty@1sce.ipsl.fr

412 route de Resteigne, 5580 Auffe, Belgium

5 Faculté Polytechnique de Mons (GEFA) Rue de Houdain 9,

B-7000 Mons quinif@fpms.ac.be isotopic composition of rain and seepage water and modern calcite precipitated in the cave, sampled between May 1995 and August 1998 at different sites in the Père Noël cave (Fig. 1 and 2). During threemonthly in-situ sessions, cave-air temperature and $\mathrm{pCO}_{2}$ and seepage-water temperature and drip rate were measured. Samples of cave water and cave calcite including some months-old calcite were taken and analysed at the laboratory for respectively their $\delta^{18} \mathrm{O}, \mathrm{Mg} / \mathrm{Ca}$ and $\mathrm{Sr} / \mathrm{Ca}$, and $\delta^{18} \mathrm{O}, \delta^{13} \mathrm{C}, \mathrm{Mg} / \mathrm{Ca}$ and $\mathrm{Sr} / \mathrm{Ca}$. The monitoring of the seepage water and modern calcite in the Père Noël cave gives a clear view of the hydrological and geochemical seasonal variations of the cave environment, it also brings precious information on the different controls (i.e. climatic, environmental) of the isotopic $\left(\delta^{18} \mathrm{O}\right.$ and $\left.\delta^{13} \mathrm{C}\right)$ and chemical $(\mathrm{Mg}$, $\mathrm{Sr})$ composition of Père Noël speleothems. Besides the study of the modern environment, we present here isotopic and geochemical results obtained on a Holocene stalagmite that was sampled in May 1995.

\section{CLIMATE AND VEGETATION}

The Père Noël cave $\left(50.0^{\circ} \mathrm{N}, 5.2^{\circ} \mathrm{E}, 230 \mathrm{~m}\right.$ asl) (Fig. 1 and 2) is situated about $200 \mathrm{~km}$ inland in a temperate maritime climate. The mean annual precipitation of 
the nearby meteorological station (Lessive, $3 \mathrm{~km} \mathrm{NE}$ of the cave), measured over the period 1980-1998, is $826 \mathrm{~mm}$ and the mean annual air temperature is $9.2^{\circ} \mathrm{C}$ (Royal Meteorological Institute, 1998). While the temperature displays a well marked seasonality, with cool summer and mild winter, the rainfall is spread all over the year (Fig 3). A C3 type vegetation consisting of mixed-leaf forest with oaks, beech and hazel trees covers the bedrock above the cave. The soil is $\sim 40 \mathrm{~cm}$ thick and consists of heavily rooted, unconsolidated brown earth comprising limestone fragments and residual clays. The area above the cave is property

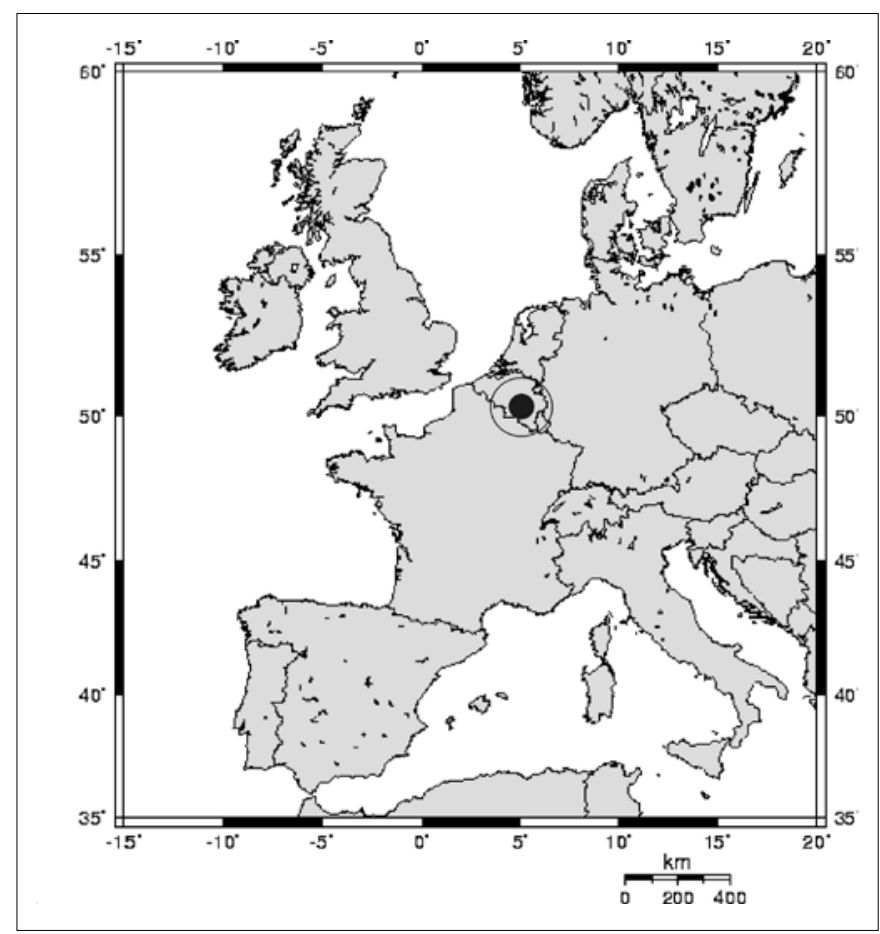

Fig. 1. Location of the Père Noël cave $\left(50.0^{\circ} \mathrm{N}, 5.2^{\circ} \mathrm{E}, 230 \mathrm{~m}\right.$ asl). of the touristic caves and is preserved from direct human influence.

\section{GEOLOGY AND SAMPLING LOCATION}

The Père Noël cave opens in Givetian limestone (Delvaux de Fenffe, 1985) with partly dolomitised beds. Overlying host rock reaches a thickness of ca. $70 \mathrm{~m}$ (Fig 2 and 4) (Vandersleyen, 1967; Verheyden et al., 2000). The cave is a result of the meander cutting of the Lesse river through the Massif de Boine (Quinif \& Bastin, 1986; Quinif, 1977) as shown by the presence of numerous pebbles of 10 to $20 \mathrm{~cm}$ diameter in the Salle du bivouac. The original river does not flow through the cave anymore since more than $\sim 150,000$ years B.P (Quinif \& Bastin, 1986). The water entering the cave today consists only of local rain, seeping directly through the overlying limestone and a small water flow from unknown origin and visible at only two places in the cave. The narrow entrance, which is situated near the top of the hill, was closed with a door after its discovery to prevent vandalism. After a steep descend of $\sim 25$ meters, a small passage leads to a first small room. A second steep descend of $\sim 20$ meters leads to a second room, the Salle $d u$ bivouac. It is the biggest room of the cave which is $\sim 50$ meters large, 200 meters long and $\sim 30$ meters high. Our study was performed in this place where six locations were regularly sampled: three at the entrance of the room (3,4 and 6 in Fig. 2) and three at the back of the room (1,2 and 5 in Fig. 2) and in the narrow sideway passage, the Chambre à coucher, in which the automatic monitoring was performed (Location $\mathrm{M}$ in Fig. 2). Most sites are actively dripping which is convenient for the water sampling, however other locations were sampled occasionally when water was

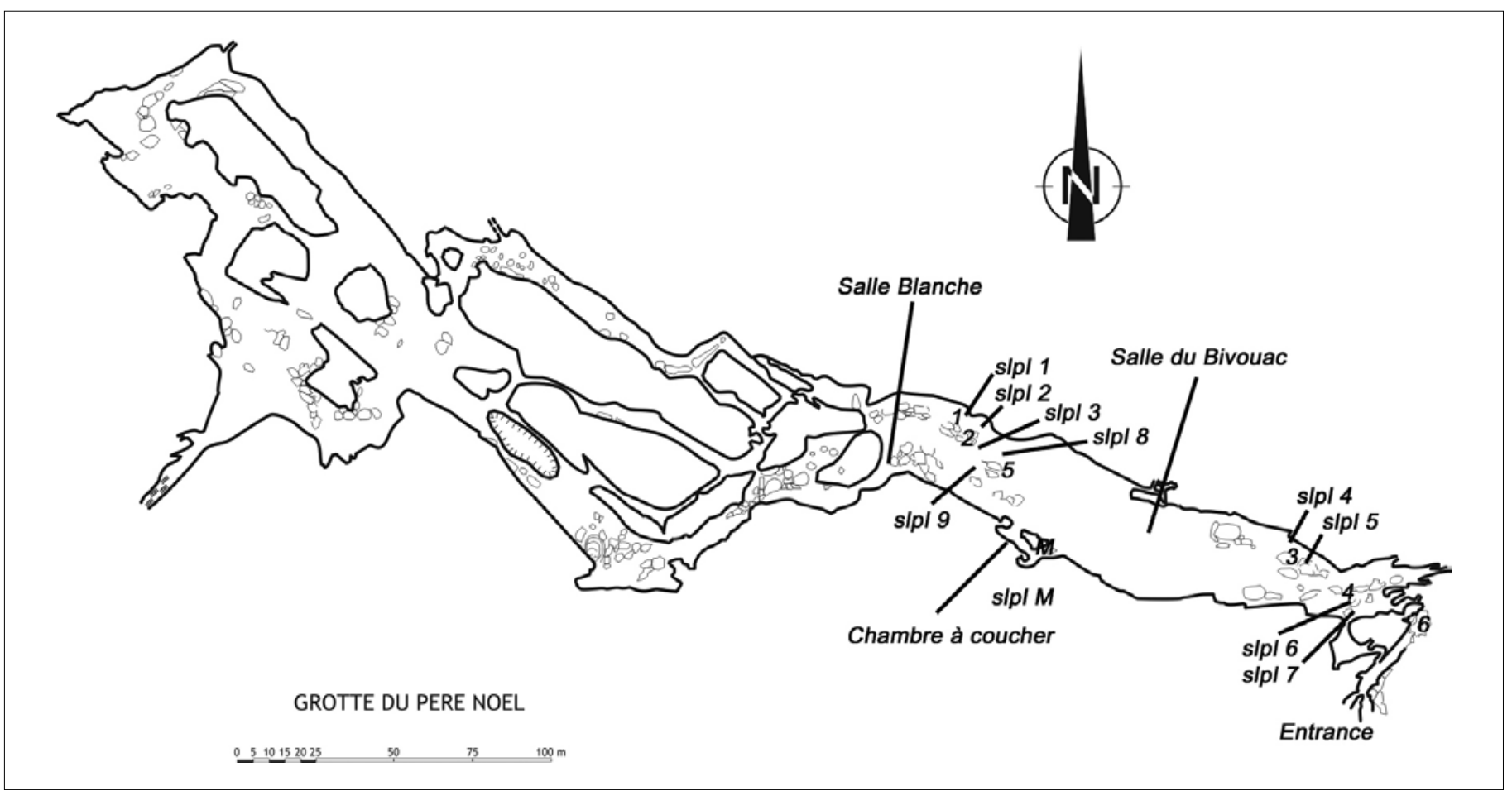

Fig.2. Map of the Père Noël cave with indication of the sampling locations. Slpl labels refer to the locations of the glass slabs for the sampling of nowadays precipitated calcite. The Holocene stalagmite was sampled at location 1. Based on map of P. Vandersleyen (1967). 


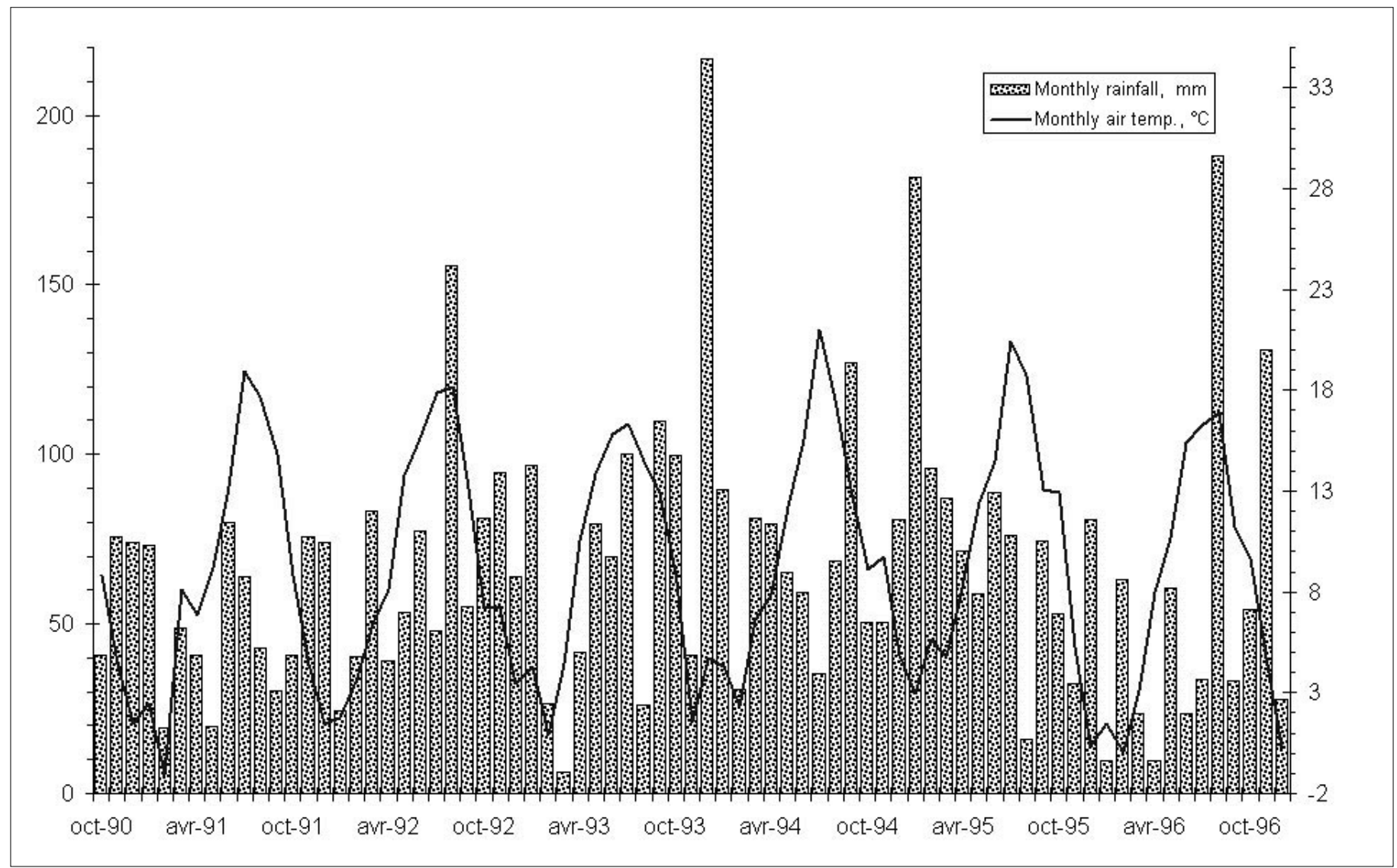

Fig. 3. Mean temperature and mean rainfall for the period 1990-1996 at the Lessives station, located 3 km NE of the Père Noël cave (Royal Meteorological Institute).

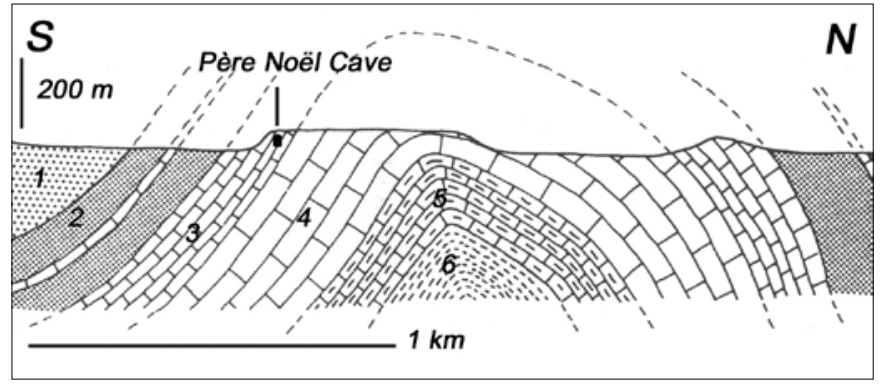

Fig. 4. Geological cross section of the Père Noël cave area.

1: Frasnian black shales; 2: Givetian limestone - Formation de Fromelennes; 3: Givetian limestone - Formations deTrois Fontaines, Terre d'Haurs and Mont d'Haurs; 4 and 5 : Eifelian limestone and calcareous shales ; 6 : Eifelian shales.

available. Most of speleothems of the Père Noël Cave are candle shaped calcite stalagmites (Fig. 5), others consist of huge columns, sometimes broken, rounded stalagmites and draperies (Fig. 6, 7).

\section{SEASONAL CHANGES IN THE CAVE CLIMATOLOGY}

The cave air temperature in the Salle du bivouac and La chambre à coucher sideway (measured with a thermocouple $\mathrm{T}$ type Testo thermometer with an accuracy of $\pm 0.3^{\circ} \mathrm{C}$ ), varies between $8.5^{\circ}$ and $9.3^{\circ} \mathrm{C}$ (Table 1). Despite the significant differences between measurements, there is no well marked seasonal variation in the cave air temperature (Fig. 8). The mean cave temperature $\left(9.0^{\circ} \mathrm{C}\right)$ corresponds within uncertainty $\left(2 \sigma \sim 0.2^{\circ} \mathrm{C}\right)$ to the mean annual temperature of the air $\left(9.2^{\circ} \mathrm{C}\right)$ at the nearby Lessives station over the sampling period 1988 - 1998 (Royal Meteorological Institute, 1998). Seepage water temperature is generally slightly warmer than the cave air temperature (Fig. 5). Highest temperatures $\left(10.2^{\circ} \mathrm{C}\right)$ were measured in July 1996 while lowest temperatures occurred in August 1998. The water temperature is not location dependent.

The $\mathrm{P}_{\mathrm{CO} 2}$ of the cave air measured using a Dräger pump system ( $\sigma \sim \pm 30 \mathrm{ppmv})$ shows strong seasonal variations from $350 \mathrm{ppmv}$ at the end of winter to $650 \mathrm{ppm}$ with occasional maxima up to $1000 \mathrm{ppm}$ at the end of summer (Table 1). This variation can be related to the seasonal production of $\mathrm{CO}_{2}$ by the vegetation and bacterial activity in the soil, entering the cave through fractures and by degassing (Ek, 1979; Gewelt \& Ek, 1983). Because $\mathrm{CO}_{2}$ content of the cave air is not very high compared to other Belgian caves where concentrations up to $\sim 8000 \mathrm{ppm}$ (Gewelt \& Ek, 1986) and exceptionally up to 15000

Table 1. Cave air temperature $\left(T_{c a}\right)$, seepage water temperature $\left(T_{s w}\right)$ and driprate of the seepage water and $\mathrm{P}_{\mathrm{CO} 2}$ of the cave air measured every two to three months between October 1995 and August 1998 in the Père Noël Cave (Han-sur-Lesse, Belgium).

\begin{tabular}{|c|c|c|c|c|}
\cline { 2 - 5 } \multicolumn{1}{c|}{} & $\mathbf{T}_{\mathrm{ca}},{ }^{\circ} \mathbf{C} \mathbf{\pm 0 . 3}$ & $\mathbf{T}_{\text {sw }},{ }^{\circ} \mathbf{C} \mathbf{\pm 0 . 3}$ & $\begin{array}{c}\text { Driprate, drips/ } \\
\text { min }\end{array}$ & $\begin{array}{c}\mathbf{P C O}_{2}, \mathbf{p p m} \\
\mathbf{\mathbf { 3 0 }}\end{array}$ \\
\hline Mean & 9.0 & 9.2 & 10.6 & 514 \\
\hline Range & 0.8 & 1.4 & 99.9 & 650 \\
\hline Minimum & 8.5 & 8.8 & 0.1 & 350 \\
\hline Maximum & 9.3 & 10.2 & 100.0 & 1000 \\
\hline Count & 56 & 25 & 69 & 14 \\
\hline
\end{tabular}




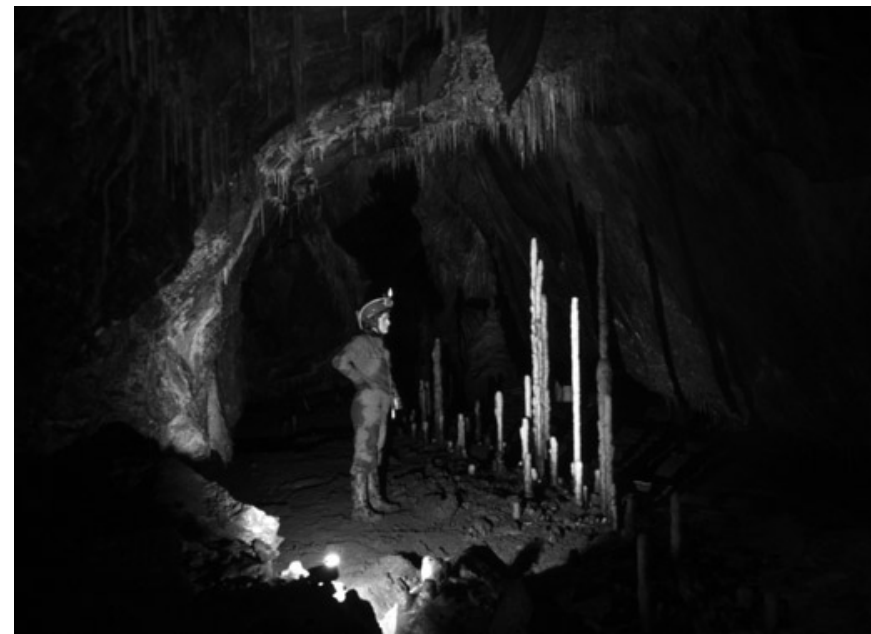

Fig. 5. Candle shaped stalagmites are very common in the Père Noël cave.

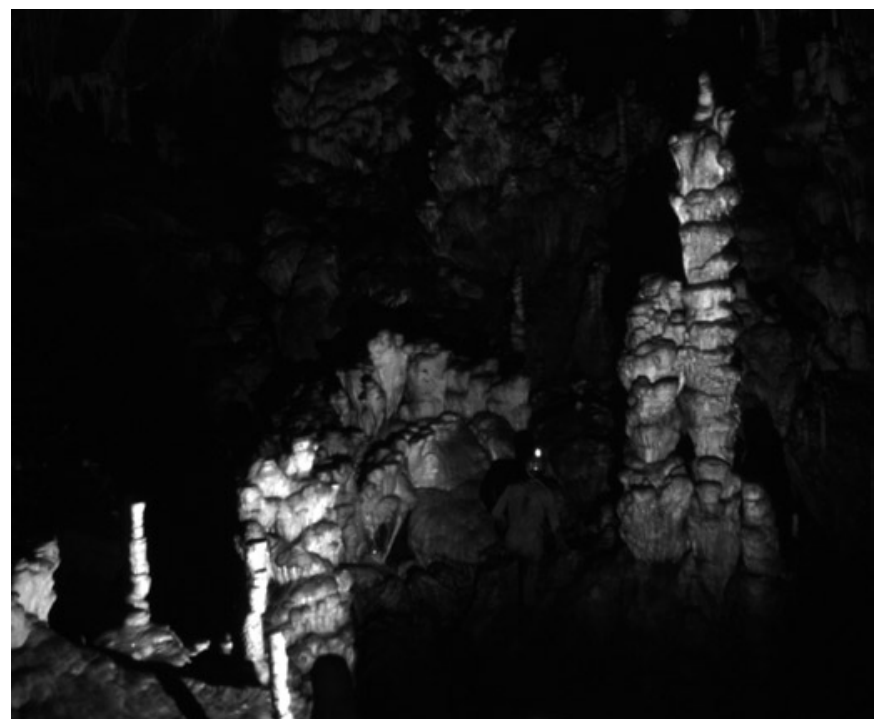

Fig. 6. Big stalagmites, sometimes broken, are present mainly in the Salle du Bivouac.

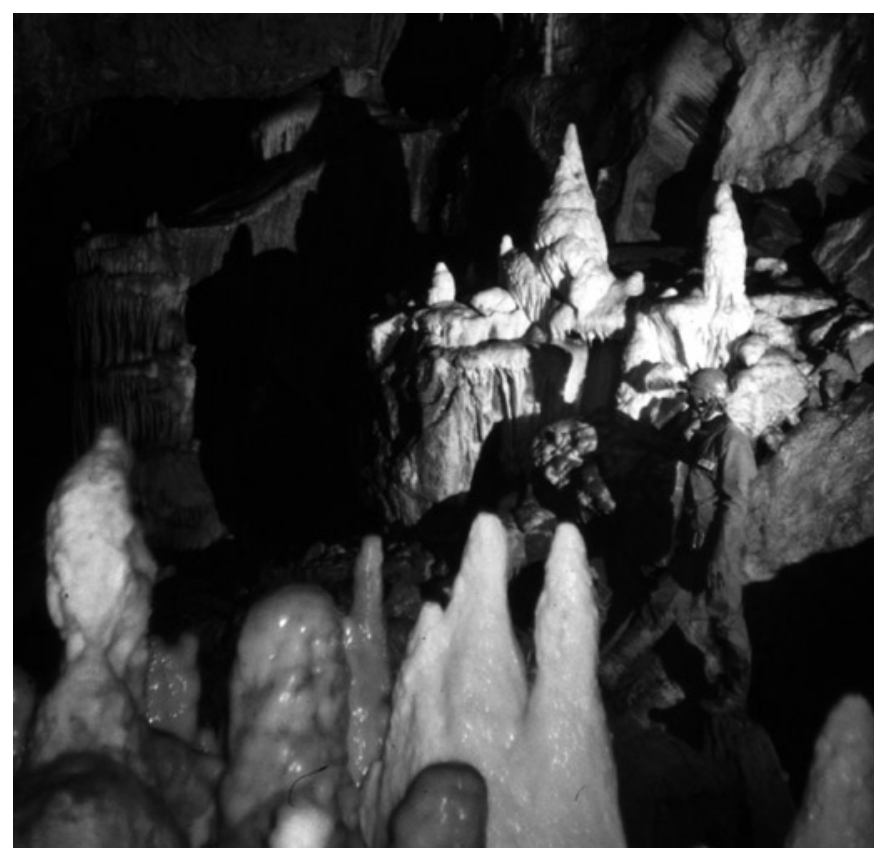

Fig. 7. Different types of speleothems are very close: older ones and present-day still active white deposits, candle shaped, rounded or huge stalagmites, sometimes broken give the impression of a chaotic ensemble. ppm (Verheyden, 2001) are often observed, it is likely that exchanges between cave air and external air are relatively important.

The relative humidity, measured with a classical hair hygrometer, varied between $95 \%$ and $98 \% \pm 5 \%$, no seasonality was observed but may be due to the low accuracy of the measurement above $95 \%$ humidity.

\section{SEASONAL CHANGES IN THE CAVE HYDROLOGY}

\section{Monitoring of cave hydrology}

The drip monitoring of the Père Noël Cave was among the first in the world; it was installed by G. Deflandre, B. Bastin, S. Colet and J.M. Robert (RSH: Recherche Scientifique Han-sur-Lesse, Hansur-Lesse, Belgium) during the summer of 1991 in the "Chambre à coucher" room, $70 \mathrm{~m}$ under the surface, just under a soda-straw stalactite. The drip rate was measured by electroluminescent diodes located a few centimeters below the tip of the stalactite. The water was then collected in a closed $100 \mathrm{ml}$ glass where the conductivity and $\mathrm{pH}$ probes are situated. Besides drip counting, the water volume was also measured thanks to a tipping-bucket system $(2 \times 50 \mathrm{ml})$. Two other sensors measured the air temperature and pressure. All measurements: air temperature, air pressure, $\mathrm{pH}$, conductivity, drops number and discharge volume were stored in RAM memory every 10 minutes and are transfered onto a PC computer with a specialised hardware board every 60 days at maximum. This automatic station was working from 1991 to 1999.

Main results of this monitoring are the following (Genty \& Deflandre, 1998):

- demonstration of a well marked seasonal signal in the drip rate (Fig. 9) mainly controlled by the water excess changes during five studied hydrological cycles; the stalactite flow rate can be split into three stages: 1) a drip rate increase during late autumn; 2) a winter-spring wet period; 3) a recession period during summer and autumn; the occurrence of a seasonal variation in the stalactite drip rate might be the main cause of annual laminations found in speleothems;

- characterization of the autumn drip rate increase by a drastical increase of the water conductivity suggesting that the "autumn flush" brought a water rich in minerals and/or organic matter (OM) into the karst. These OM components such as fulvic and humic acids might be due to the intense biological activity of the spring and summer;

- at the day scale, anticorrelation between the air pressure changes and the drip rate wiggles was observed during some periods of the year; this was explained by a rock formation constraint, i.e. the atmospheric pressure reduces or widens the conduits diameter and fissures thickness.

- Other interesting features have been observed in this monitoring, for example, an "oscillatory regime" occurred, superimposed to the day-scale wiggles, during the wet periods. These instabilities were linked to a chaotic behaviour that occurs when the flow rate is above a threshold (Fig. 10). Thanks to both 


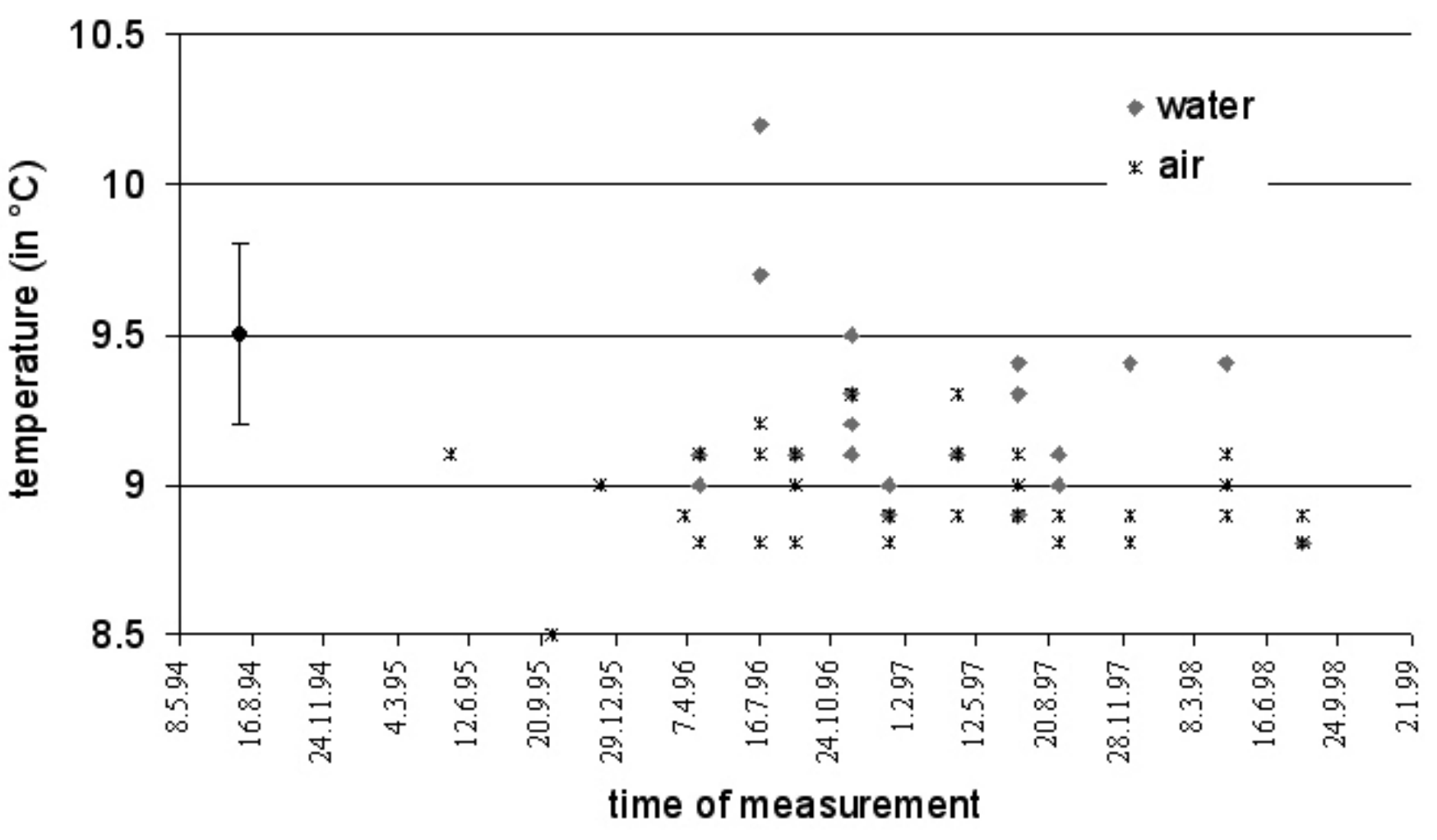

Fig. 8 Temperature of Père Noël cave air and seepage water between May 1995 and August 1998. The vertical line at the left side gives the uncertainty on the measurement.

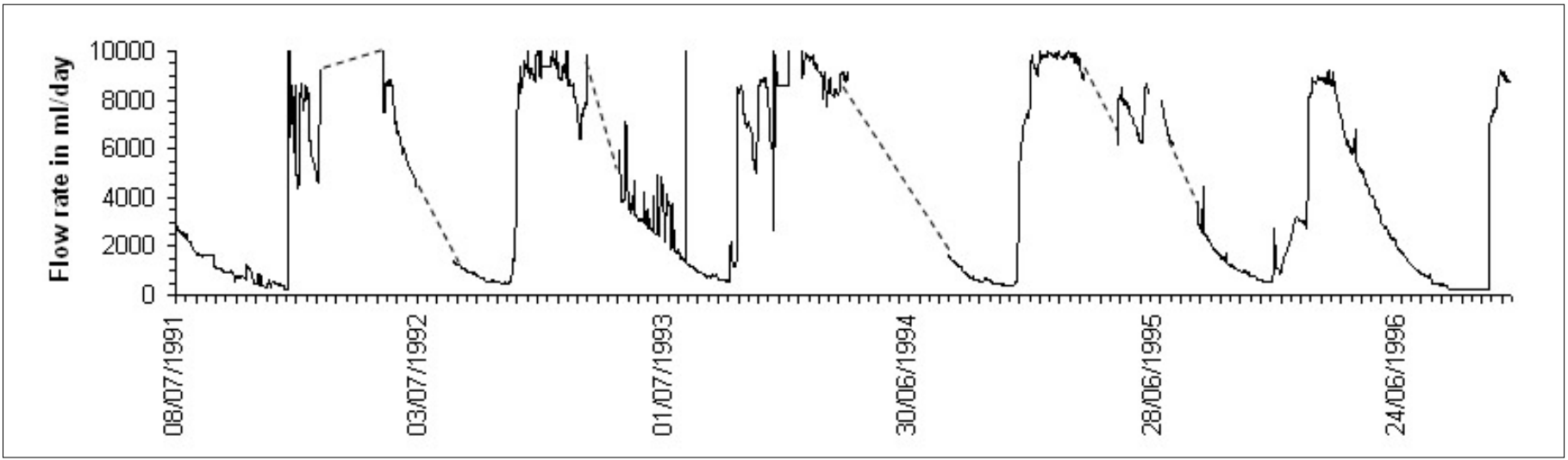

Fig. 9. Flow rate time series of the Père-Noël automatic station between 1991 and 1996 . Note the well marked seasonality of the flow rate (estimated with the drip rate counting and the drop volume calibration) (from Genty \& Deflandre, 1998).

drip counting and drip flow measurements, the drop volume could be measured and turned to be constant $(0.14 \mathrm{ml})$ for more than $94 \%$ of the studied hydrological cycles. An interesting feature is that, for extreme drip rates, the drop volume varies significantly: at low drip rate it increases because of surface tension forces, but at high flow rate, the drop volume decreases possibly because satellite drops are then formed (Genty \& Deflandre, 1998).

\section{Manual monitoring : Seasonal changes in the seepage water isotopic and trace element composition.}

Thanks to the continuous data of the automatic station, Genty and Deflandre (1998) showed that the interannual stalactite drip rate variation is controlled by the yearly water excess (rainfall minus evapo-transpiration). Is all the dripping water which flows through the stalactite during one hydrological year derived from the rainfall of the same year ? Since the seepage-water drip-rate shows a strong seasonal signal but that water dripping never stops, the seepage water should be composed of reservoir water. Different processes can be suggested: 1 . Most of the dripping water comes from the same year's rainfall, 2. The dripping water is a reservoir of water mixed and stored for more than one year in pores and the micro-fissure network, which is pushed by the yearly rainfall increase like a piston flow system and 3 . The water is a mix of recent rainfall water and older reservoir water (Genty \& Deflandre, 1998).

\section{Isotopic composition}

The $\delta^{18} \mathrm{O}$ of the seepage water $\left(\delta^{18} \mathrm{O}_{\mathrm{sw}}\right)$ varied from $-8.0 \%$ o to $-6.8 \%$ o $( \pm 0.2 \%$ o) vsmow and lies within the $\sim 4 \%$ variability of that of the rainwater samples from Han-sur Lesse $\left(\delta^{18} \mathrm{O}_{\mathrm{rw}}\right)$ (Table 2, Fig 11 and 12). 


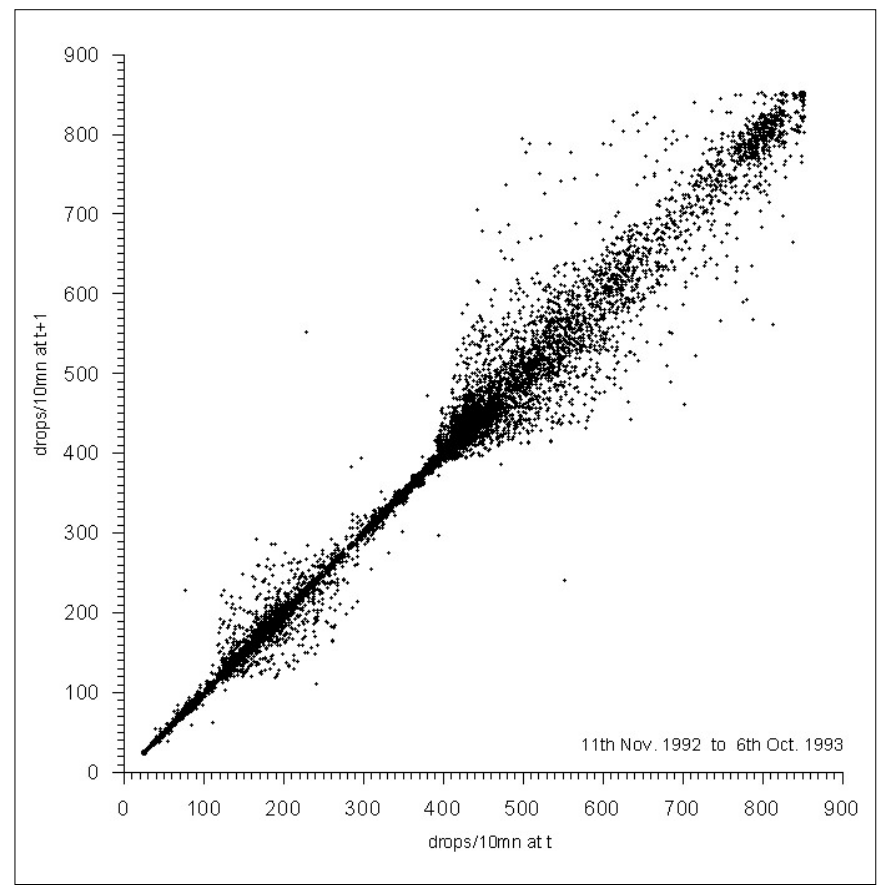

Fig. 10. Time-delay graphs of the stalactite dripping flow rate for the 1992-1993 hydrological cycle suggesting a chaotic behaviour of the dripping. Note the well marked L-shaped structures which occur when the drip rate increases (from Genty \& Deflandre, 1998).

Table 2. Mean $\delta^{18} \mathrm{O}, 1000 \mathrm{Mg} / \mathrm{Ca}$ and $1000 \mathrm{Sr} / \mathrm{Ca}$ of the Père Noël cave seepage water at all locations.

\begin{tabular}{|c|c|c|c|}
\cline { 2 - 4 } \multicolumn{1}{c|}{} & $\begin{array}{c}\mathbf{\delta}^{18} \text { Osw } \\
\mathbf{\pm 0 . 2}\end{array}$ & $\begin{array}{c}\mathbf{1 0 0 0 M g / C a} \\
\mathbf{\pm 1 5 \%} \text { on the value }\end{array}$ & $\begin{array}{c}\mathbf{1 0 0 0 S r} / \mathbf{C a} \\
\mathbf{1 1 5} \% \text { on the value }\end{array}$ \\
\hline Mean & $-7,51$ & 324 & 2,32 \\
\hline Standard Error & 0,03 & 45 & 0,15 \\
\hline Range & 1,2 & 1056 & 3,48 \\
\hline Minimum & -8.0 & 62 & 0,98 \\
\hline Maximum & $-6,8$ & 1118 & 4,46 \\
\hline Count & 73 & 40 & 40 \\
\hline
\end{tabular}

The $\delta^{18} \mathrm{O}_{\text {sw }}$ mean (on all stations during the 19951998 sampling period) is $-7.5 \pm 0.2 \%$ vsmow which is similar, within uncertainty, to the weighted regional annual mean rainwater $\delta^{18} \mathrm{O}_{\mathrm{rw}}$ of $-7.3 \%$ (Verheyden, 2001). In contrast with $\delta^{18} \mathrm{O}_{\mathrm{rw}}$, the $\delta^{18} \mathrm{O}_{\mathrm{sw}}$ exhibits only a weak seasonal variation with maximum amplitude of 1.2\%o. For locations 1, 4 and M during the year 1996, and for slpl1 during 1997, lowest values occurred in summer and the highest ones in winter which is in antiphase with the general pattern of rainfall $\delta^{18} \mathrm{O}_{\mathrm{rw}}$ (Rozanski, et al., 1993). Low $\delta^{18} \mathrm{O}_{\mathrm{rw}}$ observed for Hansur-Lesse in August 1996 and during September 1997 (Fig. 11), may explain low values for the $\delta^{18} \mathrm{O}_{\mathrm{sw}}$ for August and September 1996 in locations 1, 4 and $\mathrm{M}$, and for autumn 1997 in locations 1 and slpl1. However, high values in winter for $1, M$ and 4 in 1996 and for 4 in 1997 are difficult to explain and suggest that the seepage water might have a time lag of $\sim 6$ months on the rainfall. Although the smaller range of $\delta^{18} \mathrm{O}_{\mathrm{sw}}$ compared to $\delta^{18} \mathrm{O}_{\mathrm{rw}}$ indicates that important mixing occurs in the vadose water, it seems not important enough to mix water of an entire year completely. The strong increase of drip rates in autumn is therefore at several places most likely only due to the "piston effect" (i.e. new recharge water pushing down water stored into micro-fissures) with, at least for locations $1, \mathrm{M}$ and 4 during the year 1996, preferentially summer waters reaching the cave in winter and vice-versa. The seasonal and shorter-term variability in the $\delta^{18} \mathrm{O}_{\mathrm{sw}}$ excludes the existence of a simple mixed vadose-water reservoir. The hydrological and isotopic data suggest that the water reservoir above the cave seems slightly stratified. However, since low $\delta^{18} \mathrm{O}_{\mathrm{sw}}$ values seem to occur in response to low $\delta^{18} \mathrm{O}_{\mathrm{rw}}$ values, and because uranine dye tests have shown the first arrival of the dye after one week at some places in the Salle du Bivouac (Deflandre, oral communication), other processes, including the occurrence of rapid transfers between surface and the cave, must be considered. The local differences in seepage water hydrology does not seem to affect the longer-term mean $\delta^{18} \mathrm{O}$ of the seepage water, since three-year mean $\delta^{18} \mathrm{O}_{\mathrm{sw}}$ at each individual dripping site are similar within uncertainties, with values from -7.4 \pm 0.2 to $-7.8 \pm 0.2 \%$ o vsmow depending on the dripping location (Table 3).

\section{Trace element concentrations}

$1000 \mathrm{Mg} / \mathrm{Ca}$ and $1000 \mathrm{Sr} / \mathrm{Ca}$, i.e. the ratios of $\mathrm{Mg}$ or $\mathrm{Sr}$ to $\mathrm{Ca}$ concentrations (in ppm), display mean values of 324 and 2.32 respectively with an important spatial as well as temporal variability indicated by the range of measured $1000 \mathrm{Mg} / \mathrm{Ca}$ and $1000 \mathrm{Sr} /$ $\mathrm{Ca}$ values of 1056 and 3.48 respectively (Table 2, Fig. 13). $1000 \mathrm{Mg} / \mathrm{Ca}$ and $1000 \mathrm{Sr} / \mathrm{Ca}$ ratios of the host limestone display a mean of 12.1 and 0.99 , respectively for calcite minerals and of 313.8 and 0.71 , respectively for dolomite minerals (see details in Verheyden et al., 2000).

The $1000 \mathrm{Mg} / \mathrm{Ca}$ and $1000 \mathrm{Sr} / \mathrm{Ca}$ ratios display a strong location dependence as shown in Figure 13 and 14. At single dripping locations, there are well marked variations in the concentrations, displaying significant sympathetic correlation $\left(\mathrm{R}^{2}=0.9\right)$ between $1000 \mathrm{Mg} / \mathrm{Ca}$ and $1000 \mathrm{Sr} / \mathrm{Ca}$. With exception of location 4 , the ratios seem to vary seasonally although highest values occur at summer, autumn or winter; depending on the location (Fig. 14). Since the host rock consists of partially dolomitised limestone, incongruent dissolution of dolomite in the presence of calcite may increase the $\mathrm{Mg}$ / $\mathrm{Ca}$ ratio in the seepage waters. When calcium saturation with respect to calcite is attained, continued dissolution of dolomite, generally richer in $\mathrm{Mg}$ than calcite, increases the $\mathrm{Mg} / \mathrm{Ca}$ ratio, since $\mathrm{Ca}$ is kept constant through calcite precipitation. Dolomite generally contains less strontium than calcite and continuous dissolution of dolomite and precipitation of calcite will create an inverse relationship between $\mathrm{Mg} / \mathrm{Ca}$ and $\mathrm{Sr} / \mathrm{Ca}$ in seepage waters and consequently in precipitated cave calcite (Roberts et al., 1998), which is not the case here. According to Fairchild et al (2000), a covarying Mg/ $\mathrm{Ca}$ and $\mathrm{Sr} / \mathrm{Ca}$ or the sympathetic behavior of $\mathrm{Mg}$ and $\mathrm{Sr}$ is due to prior low $\mathrm{Mg}$ calcite precipitation enriching the precipitating water. The longer the 


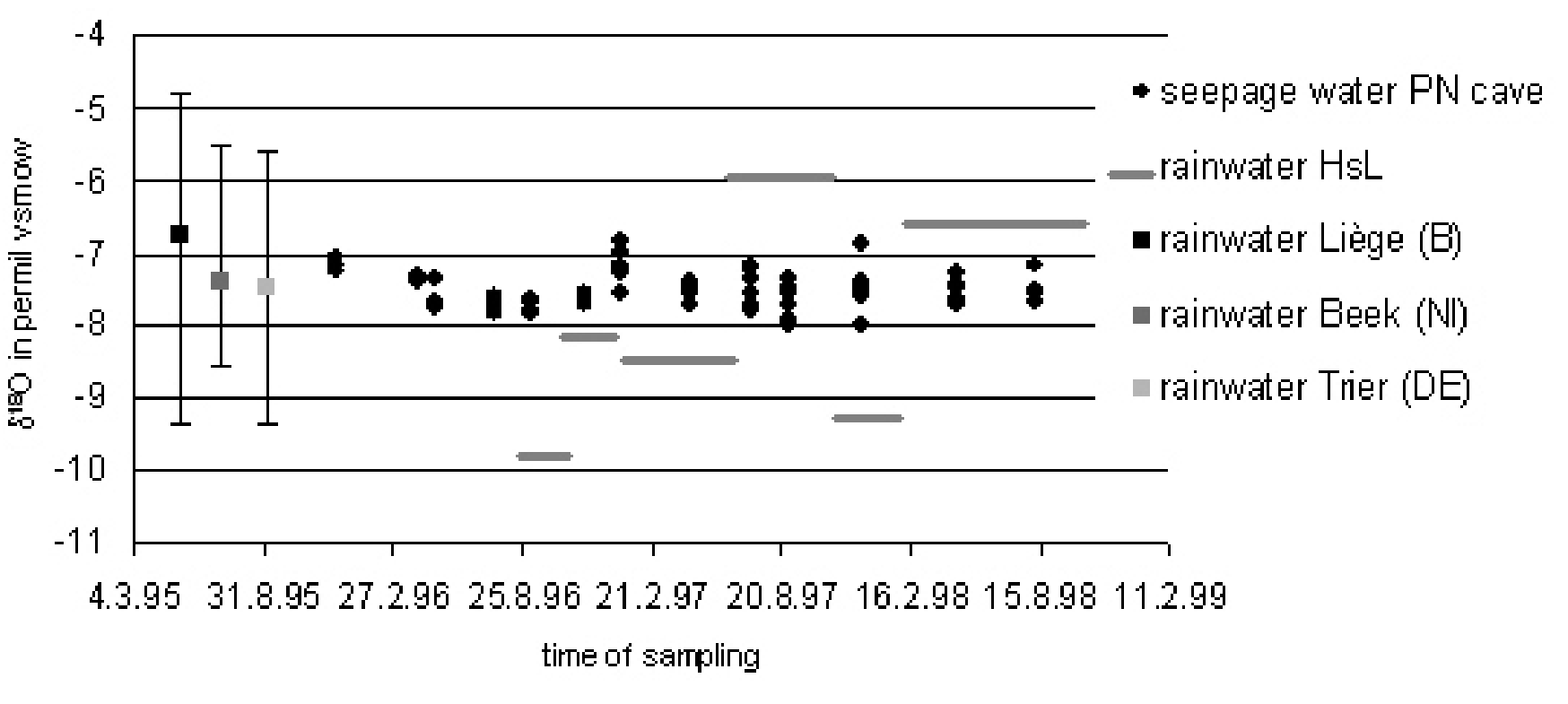

Fig. 11. Oxygen isotopic compositions of the Père Noël seepage water $\left(\delta^{18} \mathrm{Osw}\right)$ and of local rainwater $\left(\delta^{18} \mathrm{Orw}\right)$. Note that the $\delta^{18} \mathrm{O}$ of the seepage water (water collected on day of sampling and water collected in bottles left between two samplings) displays a more constant trend throughout the sampling period (1995-1998) than Han-sur-Lesse rainwater $\delta^{18} \mathrm{O}$ (weighted means of water collected between the sampling sessions). For comparison, the annual weighted mean $\delta^{18} \mathrm{O}$ of rainwater from nearby places (source: GNIP database, http://isohis.iaea.org) is also given with Y-error bars displaying the range of the monthly weighted mean $\delta^{18} \mathrm{O}$ of Liège (B) $\left(50.7 ; 5.47 ; 200 ;\right.$; $\left.66-{ }^{\prime} 70\right)$; Beek (NI) (50.9; 5.78; 111; '81-'99); Trier (DE) $(49.75 ; 6.07 ; 273$; '78-'00). Analyses were performed on a Delta E mass spectrometer at the University of Brussels using the $\mathrm{CO}_{2}$ equilibration technique (Epstein and Mayeda, 1953). Results are given in \% VSMOW with an analytical uncertainty of $\sigma 0.2 \%$ (2s)

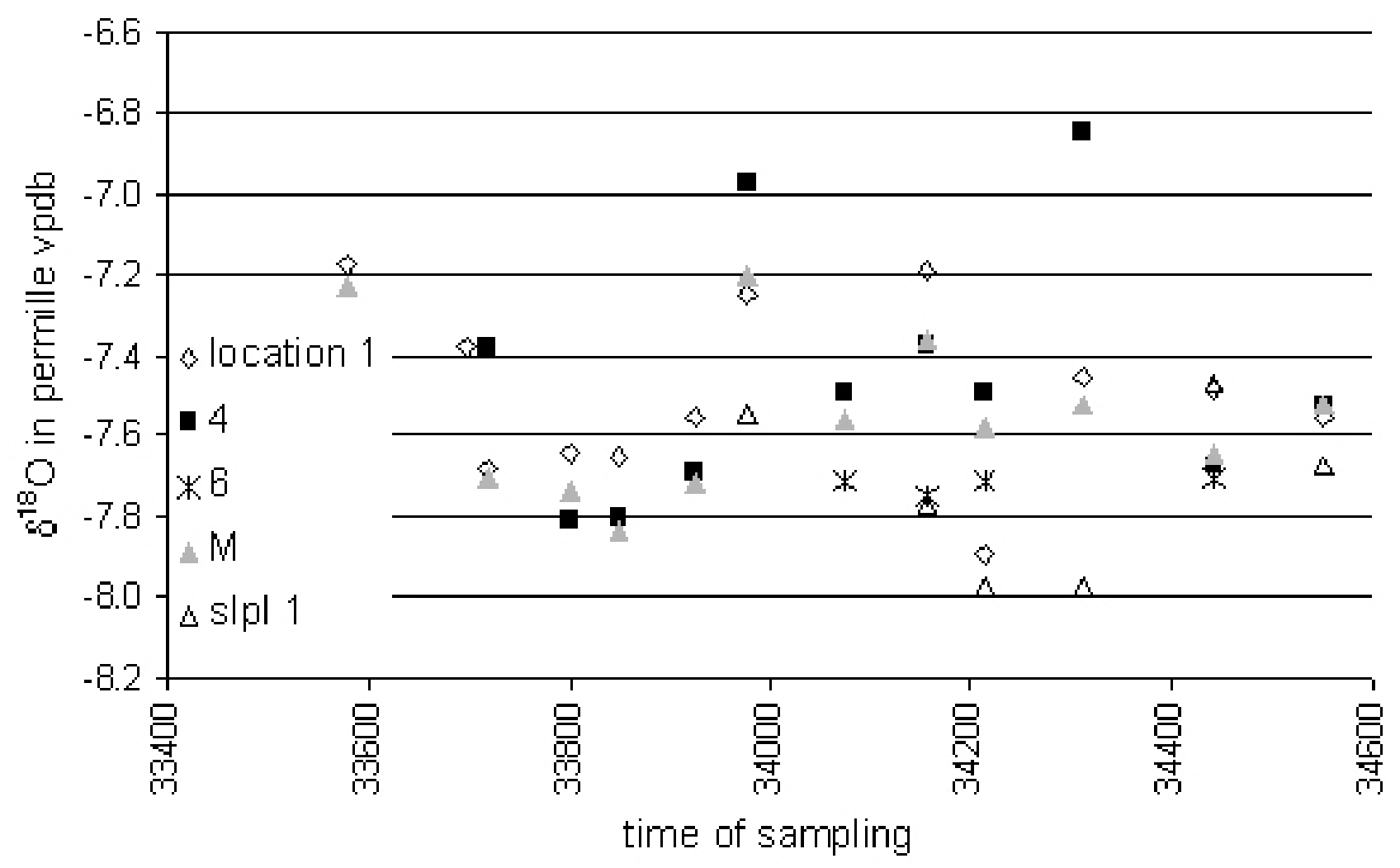

Fig. $12 \delta^{18} \mathrm{O}$ of the seepage water at different locations and different times in the Père Noël cave.

water stays in the vadose zone, the more it is controlled by precipitation-redissolution processes which enriches the remaining water in both, $\mathrm{Mg}$ and $\mathrm{Sr}$. Therefore, the $\mathrm{Mg} / \mathrm{Ca}$ and $\mathrm{Sr} / \mathrm{Ca}$ ratios of the Père Noël seepage waters seem to depend on the residence time, which depends on the water recharge and should thus be linked to the drip rate. This is confirmed for the $1000 \mathrm{Sr} / \mathrm{Ca}$ ratios where a strong relationship exists with drip rate (Fig. 15), but is less clear for the $1000 \mathrm{Mg} / \mathrm{Ca}$ ratios. 


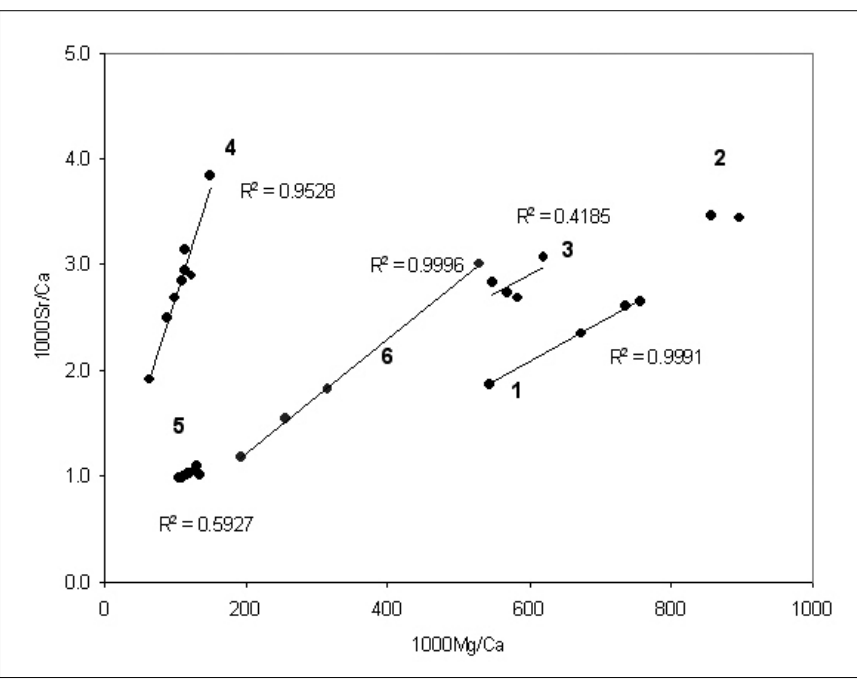

Fig. 13. $1000 \mathrm{Mg} / \mathrm{Ca}$ and $1000 \mathrm{Sr} / \mathrm{Ca}$ ratios of the Père Noël seepage water. Note the quite good correlations between $\mathrm{Mg} / \mathrm{Ca}$ and $\mathrm{Sr} / \mathrm{Ca}$ for each individual station. $\mathrm{Mg}, \mathrm{Ca}$ and $\mathrm{Sr}$ concentrations of the seepage water, acidified with a few drops of suprapur $\mathrm{HNO}_{3}$ during sampling to avoid carbonate precipitation, were measured on a Fisons-VG PlasmaQuadII+ (ICP) mass spectrometer at the Belgian Royal Museum for Central Africa with an analytical uncertainty $(1 \sigma)$ of $\pm 10 \%$.
Table 3 - Average seepage water $\delta^{18} \mathrm{O}_{\mathrm{sw}}$ and mean drip rate of the seven sampling sites of the Père Noël cave (Han-sur-Lesse Belgium). The sampling period is between October 1995 to August 1998.

\begin{tabular}{|c|c|c|c|c|}
\hline & $\begin{array}{c}\mathbf{\delta}^{18} \mathrm{O}_{\text {sw }} \text { in \% vsmow } \\
\mathbf{\pm 2 \sigma}\end{array}$ & $\mathbf{n}$ & $\begin{array}{c}\text { mean driprate } \\
\text { (drips/min) }\end{array}$ & $\mathbf{n}$ \\
\hline 1 & $-7.4 \pm 0.2$ & 12 & 0.067 & 12 \\
\hline 2 & $-7.5 \pm 0.2$ & 12 & 0.067 & 12 \\
\hline 3 & $-7.5 \pm 0.2$ & 11 & 0.075 & 11 \\
\hline 4 & $-7.5 \pm 0.3$ & 12 & 4.48 & 12 \\
\hline 5 & $\mathrm{ND}$ & & 0.10 & $\mathrm{ND}$ \\
\hline 6 & $-7.6 \pm 0.2$ & 5 & 19.76 & 5 \\
\hline $\mathrm{m}$ & $-7.8 \pm 0.2$ & 13 & 40.46 & 13 \\
\hline
\end{tabular}

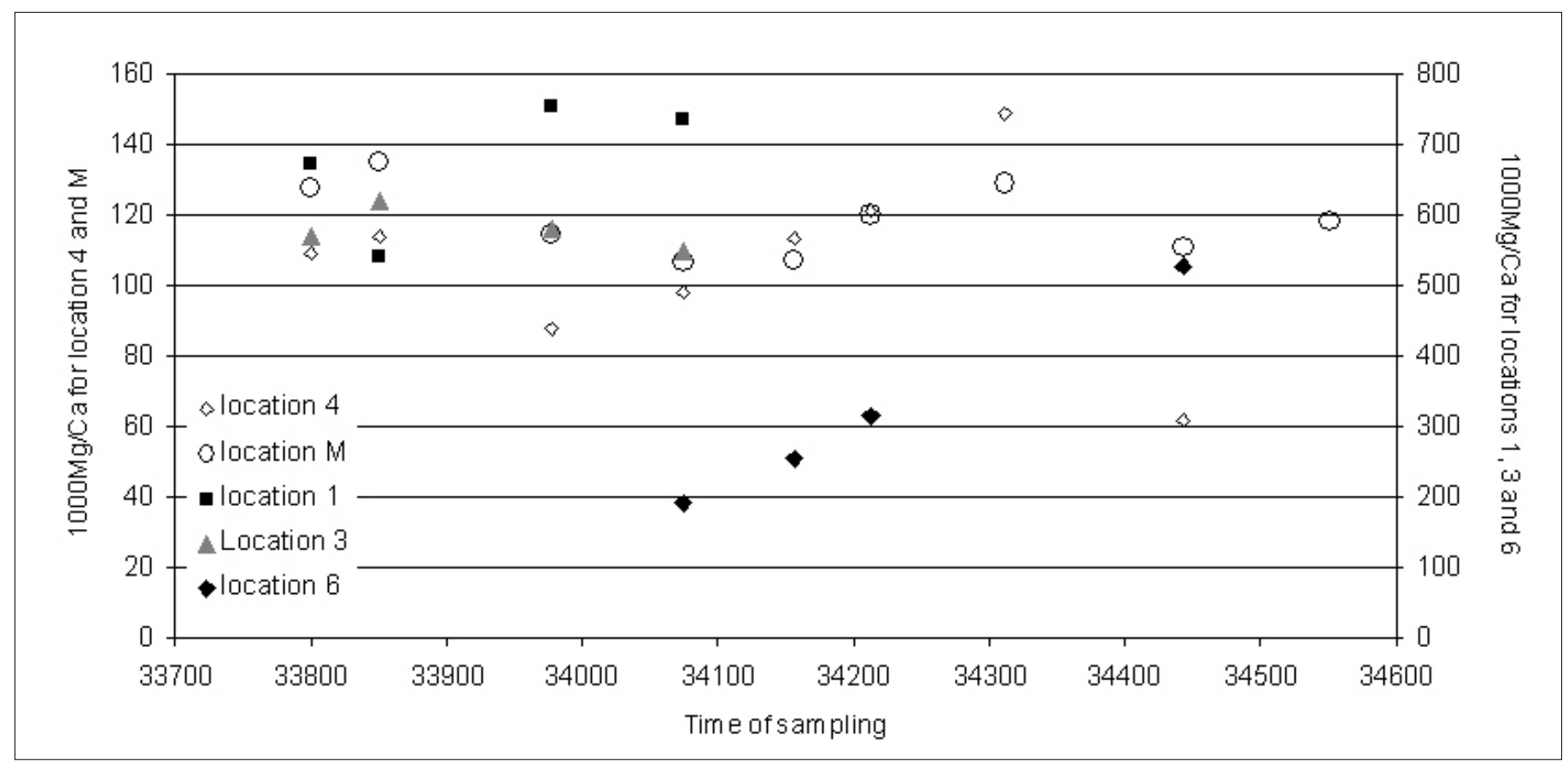

Fig. 14. $1000 \mathrm{Mg} / \mathrm{Ca}$ and $1000 \mathrm{Sr} / \mathrm{Ca}$ ratios of the Père Noël seepage waters at individual locations.

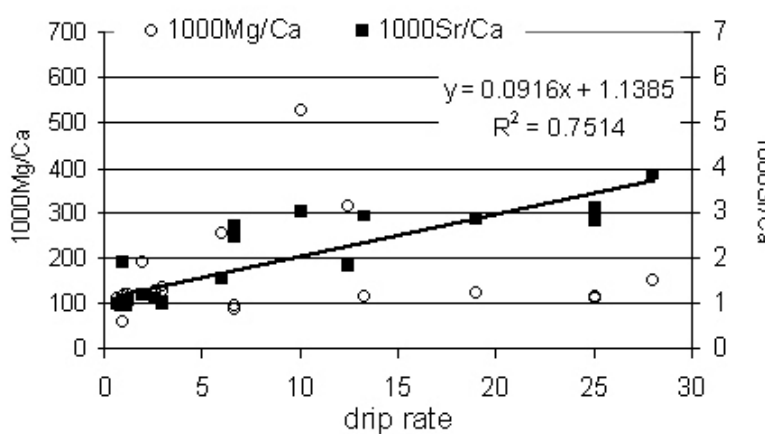

Fig. 15. A clear relation is observed between the drip rate and the $1000 \mathrm{Sr} / \mathrm{Ca}$ ratio of the seepage water. This relation is much less clear for the $1000 \mathrm{Sr} / \mathrm{Ca}$ values.

\section{MODERN CALCITE DEPOSITS}

Present day calcite was collected on glass slabs at nine dripping places and removed after between two months and 1 year, as soon as enough calcite had precipitated to permit stable isotope analysis. At the same time, recent calcite was scratched at the top of active stalagmites and collected from tips of soda straws.

$\delta^{18} \mathrm{O}_{\mathrm{pc}}$ and $\delta^{13} \mathrm{C}_{\mathrm{pc}}$ vary between -6.0 and $-3.8 \%$ o vPDB and between $-9.0 \%$ o and $-2.6 \%$ vPDB respectively. (Table 4, Fig 16). From the glass slabs experiment, we noted that where water dripped all the year, the seepage water deposited calcite the whole year through. There may exist a seasonal bias in isotopic composition of the calcite due 
to seasonal growth rate variation (Verheyden, 2001). The important range in $\delta^{18} \mathrm{O}$ and $\delta^{13} \mathrm{C}$ of the present day calcite, deposited in similar climatic and hydrologic conditions suggests that non-equilibrium processes likely occur during calcite precipitation.

\section{Deposits out of isotopic equilibrium}

Present day calcite that precipitated on glass slides, displays a significantly wider $\delta^{18} \mathrm{O}_{\mathrm{pc}}$ range $(2.3 \% \mathrm{o})$ and higher $\delta^{18} \mathrm{O}$ values than expected from the $\delta^{18} \mathrm{Osw}$ (range: $1.2 \%$ o) and from the cave temperature variations $\left(8.5^{\circ} \mathrm{C}\right.$ to $9.2^{\circ} \mathrm{C}$ ) (Fig. 17). The oxygen isotopic composition of calcite depends on the O isotopic composition of the precipitating water and on the fractionation of oxygen between water and calcite which is temperature dependent (e.g. Kim \& O'Neil, 1997). If calcite is deposited in isotopic equilibrium, oxygen isotopes of water and calcite can be used to calculate calcite precipitation temperature. Since the oxygen isotopic composition of Père Noël seepage water varies between $-8.0 \%$ and $-6.8 \%$ o vsmow and since that of present-day calcite displays values from -6.0 to $-3.7 \%$ o VPDB, calculated temperatures vary from -4.8 to $13.6^{\circ} \mathrm{C}$ (Table 5). Temperature calculations with the highest observed values of $\delta^{18} \mathrm{O}_{\mathrm{pc}}$, lead to invalid temperature values indistinctly the used temperature calculation formula, i.e. the Kim and O'Neil (1997) or the Craig (1965) formula. The calculated temperature closest to the nowadays Père Noël cave temperature is obtained with the lowest observed $\delta^{18} \mathrm{O}_{\mathrm{sw}}$ values and $\delta^{18} \mathrm{O}_{\mathrm{pc}}$ values and using the Craig (1965) formula, referred to as giving the most accurate results in he cave environment by McDermott et al. (2005). Therefore, present-day calcite with a $\delta^{18} \mathrm{O}$ value of $-6 \%$ is probably deposited close to isotopic equilibrium. Note that present-day calcite with low $\delta^{18} \mathrm{O}$ values also display low $\delta^{13} \mathrm{C}$ values. Similarly to the $\delta^{18} \mathrm{O}_{\mathrm{pc}}, \delta^{13} \mathrm{C}_{\mathrm{pc}}$ values of the calcite are higher and display more important variations (up to 6.3\%o) than expected from the presence of a dense C3 vegetation cover (between -13\%o and -9\%o) (Hendy, 1971). The enrichment in both the $\delta^{18} \mathrm{O}_{\mathrm{pc}}$ and the $\delta^{13} \mathrm{C}_{\mathrm{pc}}$ is a first sign for a non-equilibrium precipitation. The second sign of a kinetic fractionation, is the positive and significant correlation between $\delta^{18} \mathrm{O}_{\mathrm{pc}}$ and $\delta^{13} \mathrm{C}_{\mathrm{pc}}\left(\mathrm{R}^{2}=0.94\right.$ on the 99\% confidence level) (Fig. 16).

$\delta^{18} \mathrm{O}_{\mathrm{pc}}$ and $\delta^{13} \mathrm{C}_{\mathrm{pc}}$ values of calcite deposited at the same place may vary along a $\delta^{18} \mathrm{O}_{\mathrm{pc}}-\delta^{13} \mathrm{C}_{\mathrm{pc}}$ correlation line, which, we suggest, is the consequence of a variation in the degree of equilibrium during calcite precipitation: higher isotopic values are from deposits far from the equilibrium while the lowest values are close to equilibrium (Fig. 12). This correlation suggests that the calcite $\square \delta^{18} \mathrm{O}$ and $\delta^{13} \mathrm{C}$ are controlled by related processes: evaporation of the water and fast $\mathrm{CO}_{2}$ degassing (Fornaca-Rinaldi et al., 1968; Gonzales \& Lohmann, 1988). Fast $\mathrm{CO}_{2}$ degassing will mainly affect the $\delta^{13} \mathrm{C}$ (Inoue $\&$ Sugimura, 1985, Hendy, 1971) due to preferential removal of ${ }^{12} \mathrm{C}$, while evaporation will mainly affect $\delta^{18} \mathrm{O}$ by preferential removal of ${ }^{16} \mathrm{O}$ (Craig et al., 1963; Dansgaard et al., 1964) but also $\delta^{13} \mathrm{C}$ since degassing will increase synchronously to evaporation. Calcite precipitated from fast dripping
Table 4. Oxygen and carbon isotopic composition of presentday calcite from the Père Noël cave (Han-sur-Lesse - Belgium) deposited on glass slabs.

\begin{tabular}{|c|c|c|c|}
\cline { 2 - 4 } \multicolumn{1}{c|}{} & $\begin{array}{c}\delta^{18} \mathrm{O}_{\mathrm{pc}} \\
\% \mathrm{v} \text { VPDB } \\
\pm 0.1\end{array}$ & $\begin{array}{c}\delta^{13} \mathrm{C}_{\mathrm{pc}} \\
\% \mathrm{~V} \text { VPDB } \\
\pm 0.06\end{array}$ & drip rate (drips/min) \\
\hline Mean & -4.9 & -5.9 & 6.6 \\
\hline Range & 2.3 & 7.1 & 35.1 \\
\hline Minimum & -6.0 & -9.5 & 0.2 \\
\hline Maximum & -3.7 & -2.5 & 35.3 \\
\hline $\mathrm{n}$ & 24 & 24 & 34 \\
\hline
\end{tabular}

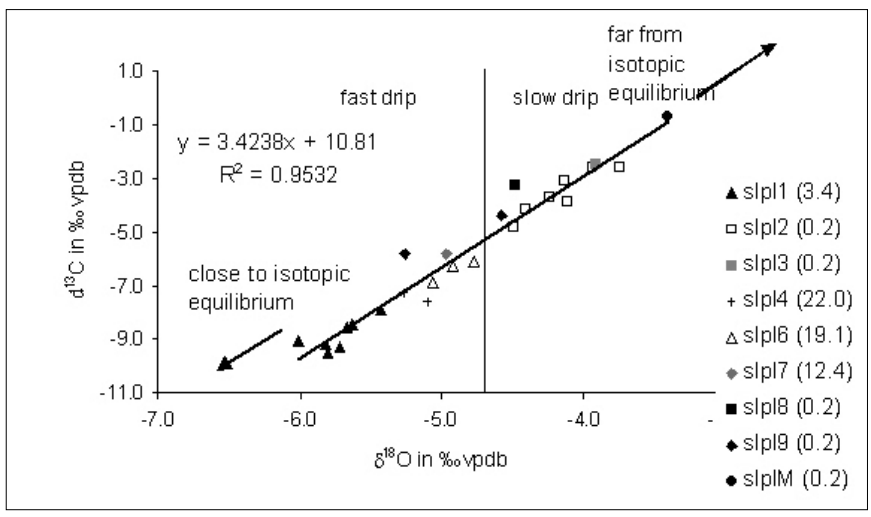

Fig. 16. Oxygen and carbon isotopic composition of present day calcite deposited on glass slabs in the Père Noël cave (Han-surLesse, Belgium). Note the temporal as well as spatial variations (see figure 2 for the locations of the different stations). The oxygen and carbon isotopic composition are positively correlated with an $\mathrm{R}^{2}$ of 0.94 at the $99 \%$ confidence level. Fast dripping water (more than $1 \mathrm{drip} /$ minute, numbers between brackets) precipitates lighter calcite. Measurements of calcite $\delta^{18} \mathrm{O}$ and $\delta^{13} \mathrm{C}$ were done the same way as for water samples after cryogenic purification of $\mathrm{CO}_{2}$ (McCrea, 1950). The values are given in \%o VPDB and analytical uncertainties are $\leq 0.1 \%$ ( $2 \sigma)$ for $\delta^{18} \mathrm{O}$ and $\leq 0.06 \%$ o $(2 \sigma)$ for $\delta^{13} \mathrm{C}$.

Table 5. Temperature calculations using the Craig (1965) and the Kim and O'Neil (1997) formulas

\begin{tabular}{|c|c|c|c|}
\hline $\begin{array}{c}\delta^{18} \mathrm{O}_{\mathrm{sw}} \\
\text { (vsmow } \pm 0.2 \% \text { ) }\end{array}$ & $\begin{array}{c}\delta^{18} \mathrm{O}_{\mathrm{pc}} \\
(\mathrm{VPDB} \pm 0.1 \%)\end{array}$ & $\begin{array}{c}\text { Calculated T } \\
\left({ }^{\circ} \mathrm{C}\right) \\
\text { Craig }(1965)\end{array}$ & $\begin{array}{c}\text { Calculated T } \\
\left({ }^{\circ} \mathrm{C}\right) \\
\text { Kim \& O'Neil }\end{array}$ \\
\hline \multirow[t]{2}{*}{$-8.0 \%$ (min.) } & $-6.0 \%$ (min.) & $9.0^{\circ} \mathrm{C}$ & $4.8^{\circ} \mathrm{C}$ \\
\hline & $-3.7 \%$ (max.) & $1.2^{\circ} \mathrm{C}$ & $-4.8^{\circ} \mathrm{C}$ \\
\hline \multirow[t]{2}{*}{$-6.8 \%$ (max.) } & $-6.0 \%$ (min.) & $13.6^{\circ} \mathrm{C}$ & $10.0^{\circ} \mathrm{C}$ \\
\hline & $-3.7 \%$ (max.) & $5.1^{\circ} \mathrm{C}$ & $0.1^{\circ} \mathrm{C}$ \\
\hline
\end{tabular}

waters display a more negative isotope composition while calcite precipitated from slow dripping water exhibits more positive isotope compositions (Fig 16). A higher drip rate will replace more rapidly the precipitating fluid and therefore limits the effect of degassing and of possible evaporation processes on the calcite isotopic composition. The low $\mathrm{P}_{\mathrm{CO} 2}$ of the Père Noël cave air (360-1000 ppm) likely favours fast $\mathrm{CO}_{2}$ degassing. However, important evaporation seems unlikely in an overall humidity of 95 to $98 \%$, therefore it remains unclear if the high and variable $\delta^{18} \mathrm{O}$ and $\delta^{13} \mathrm{C}$ values of nowadays calcite are due to evaporation and fast degassing processes or to other kinetic effects linked to precipitation dynamics

$\delta^{18} \mathrm{O}$ and $\delta^{13} \mathrm{C}$ of other recent calcite from the 


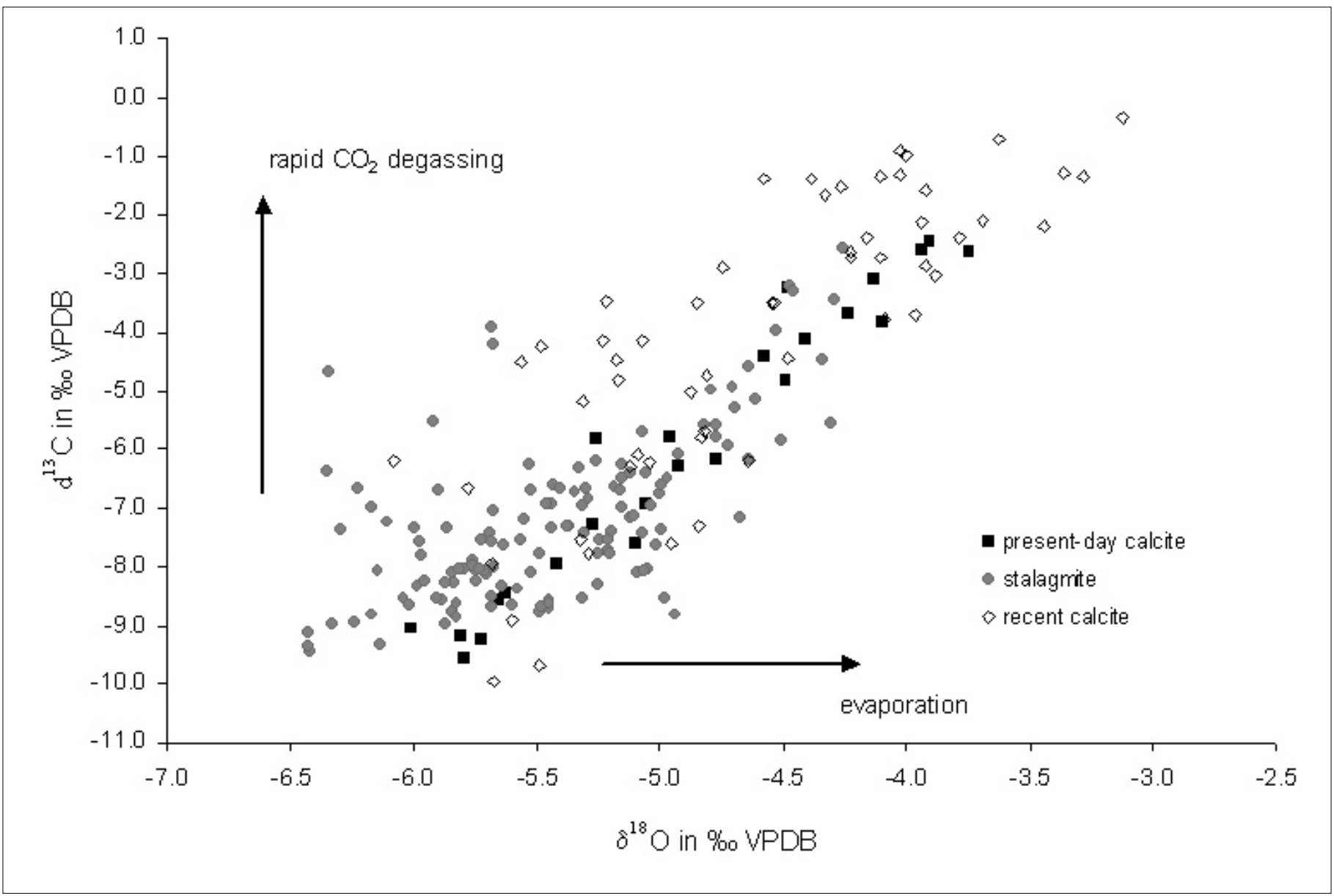

Fig. 17. Oxygen and carbon isotopic composition of all the Père Noël cave calcite studied : nowadays calcite deposited on glass slabs, subsamples along the vertical axis of the Holocene stalagmite PN-95-5 and recent tips of soda straws and of tops of stalagmites. Note that all of these deposits display a positive covariation between $\delta^{18} \mathrm{O}$ and $\boldsymbol{\delta}^{13} \mathrm{C}$ suggesting changes in the degree of isotopic equilibrium.

Père Noël cave, i.e. presumed recent tips of soda straws and tops of stalagmites, display the same trend $\left(\mathrm{R}^{2}=0.64\right.$ on the $99 \%$ confidence level) (Table 6, Fig. 17) as observed in the present-day calcite. Therefore, variations in $\delta^{18} \mathrm{O}$ and $\delta^{13} \mathrm{C}$ observed in recent calcite, deposited on a longer period (i.e. several years to several centuries) are likely also due to the degree of isotopic equilibrium, linked with drip rate and consequently, through recharge, with rainfall.

Measurements of the $\mathrm{Mg} / \mathrm{Ca}$ and $\mathrm{Sr} / \mathrm{Ca}$ ratios in recent calcite show a significant correlation (Table 6, Fig. 18), inherited from the already existing correlation in the seepage waters. The $\mathrm{Mg} / \mathrm{Ca}$ and $\mathrm{Sr} / \mathrm{Ca}$ ratios in the calcite are therefore, as the ratios in the seepage water, dependent on the seepage water residence time.

\section{PALAEOCLIMATIC RECONSTRUCTION IN THE LIGHT OF THE PRESENT-DAY, EXAMPLE OF THE HOLOCENE STALAGMITE PN-95-5}

\section{Petrography, age and growth period}

A Holocene calcite stalagmite, ca. $65 \mathrm{~cm}$ long and with a mean diameter of $10 \mathrm{~cm}$, was sampled at $300 \mathrm{~m}$ from the entrance at location slpl1 (Fig. 2). The stalagmite is composed of an alternation of dark brown and milky white calcite (Fig. 19). Growth layers are visible over nearly the entire length, however not always easily countable. No hiatus is observed. The growth period, from $13 \mathrm{ka}$ to $2 \mathrm{ka}$, was constrained by ten TIMS U-Th ages (Fig. 19).

\section{Isotopic and Chemical Holocene records}

Subsamples for $\delta^{18} \mathrm{O}$ and $\delta^{13} \mathrm{C}$ analyses were drilled every $5 \mathrm{~mm}$ along the central growth axis of the speleothem. $\mathrm{Mg} / \mathrm{Ca}$ and $\mathrm{Sr} / \mathrm{Ca}$ measurements in the same stalagmite are reported by Verheyden et al. (2000) and are used here for comparison with the oxygen and carbon isotopic profiles. Sr isotopic measurements are reported and discussed in Verheyden et al. (2000) and are not considered here.

The $\delta^{18} \mathrm{O}$ displays changes between $-6.4 \%$ and $-4.3 \%$ vPDB. $\delta^{13} \mathrm{C}$ varies between $-9.5 \%$ and $-2.6 \%$ VPDB and displays parallel changes as $\delta^{18} \mathrm{O}$ along the vertical axis of the stalagmite (Table 7 , Fig. 17). $\delta^{18} \mathrm{O}$ and $\delta^{13} \mathrm{C}$ measurements along single growth layers were performed at ten different heights in order to check the isotopic equilibrium (Hendy, 1971).

\section{Chemical and isotopic composition trends along a single growth layer}

A significant covariation is observed between $\delta^{18} \mathrm{O}$ and $\delta^{13} \mathrm{C}$ in 6 layers, indicating non-equilibrium deposition (Fig. 20). As for the stable isotopes, we have tried to see the lateral variation of the $\mathrm{Mg} / \mathrm{Ca}$ and $\mathrm{Sr} / \mathrm{Ca}$ ratio along a single laminae of the PN-95-5 stalagmite where 
Table 6. Oxygen and carbon isotopic composition of recent calcite (top of stalagmites and tip of soda straws) from the Père Noël cave (Han-sur-Lesse, Belgium).

\begin{tabular}{|c|c|c|c|c|}
\hline & $\begin{array}{c}\delta^{18} O_{r c} \\
\% o \text { VPDB } \\
\pm 0.1 \\
\end{array}$ & $\begin{array}{c}\delta^{13} C_{\mathrm{rc}} \\
\% \% \text { VPDB } \\
\pm 0.06 \\
\end{array}$ & $\begin{array}{c}1000 \mathrm{Mg} / \mathrm{Ca} \\
\pm 15 \% \text { on the } \\
\text { value }\end{array}$ & $\begin{array}{c}1000 \mathrm{Sr} / \mathrm{Ca} \\
\pm 15 \% \text { on the value }\end{array}$ \\
\hline Mean & -4.6 & -4.1 & 15.9 & 0.4 \\
\hline Standard & 0.1 & 0.3 & 1.5 & 0.1 \\
\hline Range & 3.0 & 9.6 & 47.9 & 2.4 \\
\hline Minimum & -6.1 & -10.0 & 3.3 & 0.1 \\
\hline Maximum & -3.1 & -0.3 & 51.3 & 2.5 \\
\hline Count & 56 & 56 & 45 & 46 \\
\hline
\end{tabular}

Table 7. $\delta^{18} \mathrm{O}, \delta^{13} \mathrm{C}, 1000 \mathrm{Mg} / \mathrm{Ca}$ and $1000 \mathrm{Sr} / \mathrm{Ca}$ changes along the longitudinal axis of the Père Noël stalagmite.

\begin{tabular}{|c|c|c|c|c|}
\hline & $\begin{array}{c}\delta^{18} \mathrm{O} \\
\text { in } \% 0 \text { VPDB } \\
\end{array}$ & $\begin{array}{c}\delta^{13} \mathrm{C} \\
\text { in \%o VPDB }\end{array}$ & $\begin{array}{c}1000 \mathrm{Mg} / \mathrm{Ca} \\
\pm 15 \% \text { on the } \\
\text { value }\end{array}$ & $\begin{array}{c}1000 \mathrm{Sr} / \mathrm{Ca} \\
\pm 15 \% \text { on the } \\
\text { value }\end{array}$ \\
\hline Mean & -5.4 & -7.2 & 9.5 & 0.2 \\
\hline $\begin{array}{l}\text { standard } \\
\text { deviation }\end{array}$ & 0.5 & 1.4 & 3.5 & 0.0 \\
\hline Range & 2.2 & 6.9 & 20.9 & 0.2 \\
\hline Minimum & -6.4 & -9.5 & 4.7 & 0.1 \\
\hline Maximum & -4.3 & -2.6 & 25.6 & 0.3 \\
\hline Count & 130 & 130 & 130 & 130 \\
\hline
\end{tabular}

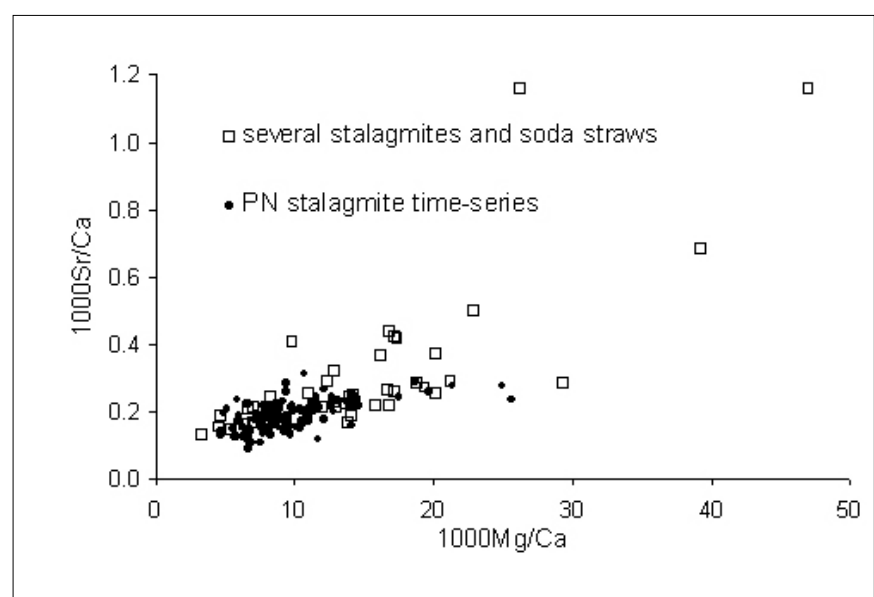

Fig. 18. $1000 \mathrm{Sr} / \mathrm{Ca}$ and $1000 \mathrm{Mg} / \mathrm{Ca}$ of recent calcite and the PN-95-5 stalagmite. Measurements were made in the same way as for cave waters after dissolution in $10 \%$ suprapur $\mathrm{HNO}_{3}$. Mean error is $\pm 15 \%$.

an isotope increase was observed towards the edges (Fig. 21). Results display a similar pattern between isotopes and $\mathrm{Mg} / \mathrm{Ca}, \mathrm{Sr} / \mathrm{Ca}$ ratios: they all increase significantly toward the edges and they all show a significant correlation $\left(\delta^{18} \mathrm{O}\right.$ with $\delta^{13} \mathrm{C}$ and $\mathrm{Mg} / \mathrm{Ca}$ with $\mathrm{Sr} / \mathrm{Ca}$ ) (Fig 21). $1000 \mathrm{Mg} / \mathrm{Ca}$ variation from the central axis and to about $2 \mathrm{~cm} /$ axis is $\sim 4$ which is in the range of the $\mathrm{Mg} / \mathrm{Ca}$ variations observed during the stalagmite growth (Fig. 18). It is the same for the $\mathrm{Sr} /$ $\mathrm{Ca}$ ratio. It is thus possible that a kinetic effect during the calcite precipitation on the stalagmite might be the main cause of the synchronous changes observed in all these proxies, itself controlled by the drip rate.

\section{Isotopic and chemical variations through time - link with climate.}

$1000 \mathrm{Mg} / \mathrm{Ca}$ values in the speleothem vary between $4.7 \pm 0.7$ and $25.6 \pm 3.8$ with a mean of 9.5 (Table 6, Fig. 17). At a high frequency, the changes of $\mathrm{Mg}$ and $\mathrm{Sr}$ show a striking and significant similarity during most of the stalagmite growth (Fig. 19).

The positive Hendy tests and the isotopic and elemental covariation, suggest that the $14 \mathrm{ka}$ old PN-95-5 stalagmite was deposited out of equilibrium during most of its growth.

The study of present day calcite suggests the existence of a link between isotopic equilibrium precipitation of calcite and drip rate (linked to recharge at the cave site) (Fig. 16). Therefore, $\delta^{18} \mathrm{O}$ and $\delta^{13} \mathrm{C}$ of the stalagmite may give some information on dry / wet variations in the past: the more enriched the $\delta^{13} \mathrm{C}$ and the $\delta^{18} \mathrm{O}$ of the calcite, the wetter the climate. No quantitative relation between drip rate and calcite $\delta^{18} \mathrm{O}$ could be established. However, the time-series might give relative information on drywet episodes during the Holocene.

In contrast to other European speleothems (i.e. Villars and Chauvet speleothems, Genty et al. 2006), the Père Noël stalagmite does not display a characteristic geochemical signal for the Younger Dryas. During this period, temperature changes play a role and may "contaminate" the $\delta^{18} \mathrm{O}$ change linked with changing isotopic equilibrium conditions, itself linked with drip rate.

The striking similarity between the $\delta^{18} \mathrm{O}$ and $\delta^{13} \mathrm{C}$ time-series and the $\mathrm{Mg} / \mathrm{Ca}$ and $\mathrm{Sr} / \mathrm{Ca}$ time-series suggests a common control on these changes. Two processes may explain this relationship: 1) $\mathrm{Mg} /$ $\mathrm{Ca}$ and $\mathrm{Sr} / \mathrm{Ca}$ ratios closely depend on the $\mathrm{Mg} /$ $\mathrm{Ca}$ and $\mathrm{Sr} / \mathrm{Ca}$ ratios of the seepage waters, which on their turn depend on the residence time of the water in the vadose zone and consequently, through the recharge amount, on the rainfall amount. The dependence on the residence time might be due to the degree of "prior calcite precipitation" (PCP) that will increase (and covary) both $\mathrm{Mg} / \mathrm{Ca}$ and $\mathrm{Sr} / \mathrm{Ca}$ in the seepage water and consequently in the calcite (Fairchild et al., 2000). $\delta^{18} \mathrm{O}$ and $\delta^{13} \mathrm{C}$ variations, as observed on the present day calcite, are mainly controlled by the isotopic equilibrium state during precipitation of the calcite, which depends on the drip rate, and consequently, through recharge, on the rainfall amount too; 2) Chemical as well as isotopic composition depend on kinetic processes during calcite precipitation on the stalagmite, which are on their turn somehow linked with drip rate (as suggested by the present day calcite) and consequently with recharge. Therefore, chemical and isotopic ratios appear, in both cases, to be two proxies for the rainfall amount, independently in case 1 but linked to the same proces in case 2 .

\section{CONCLUSION}

The Père Noël cave exhibits a rather constant climatology (temperature, humidity) and only slight variations in the seepage water isotopic composition. In contrast, clear spatial and seasonal variations are observed for the stalactite drip rates and the chemical composition $(\mathrm{Mg} / \mathrm{Ca}$ and $\mathrm{Sr} /$ $\mathrm{Ca}$ ) of the cave water as well as the isotopic and chemical composition of the cave calcite. Most 


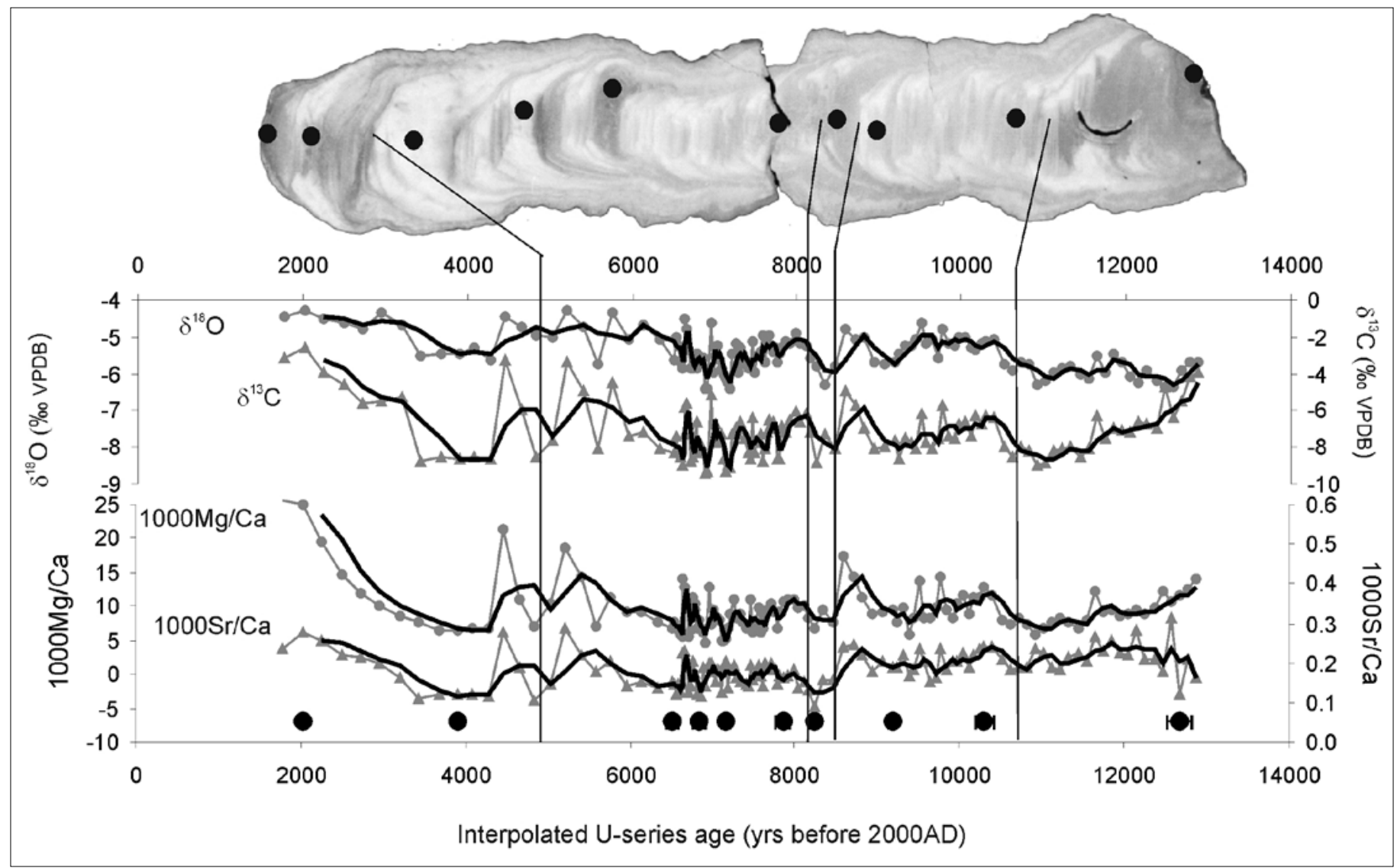

Fig. 19. Isotopic and geochemical time-series of the Père Noël stalagmite PN-95-5 in front of the polished section. Points at the bottom of the figure indicate TIMS U/Th dating with 2s errors. U-series datings were performed at the Department of Earth Sciences of the Open University, UK, following the procedure described in Verheyden et al, 2000.
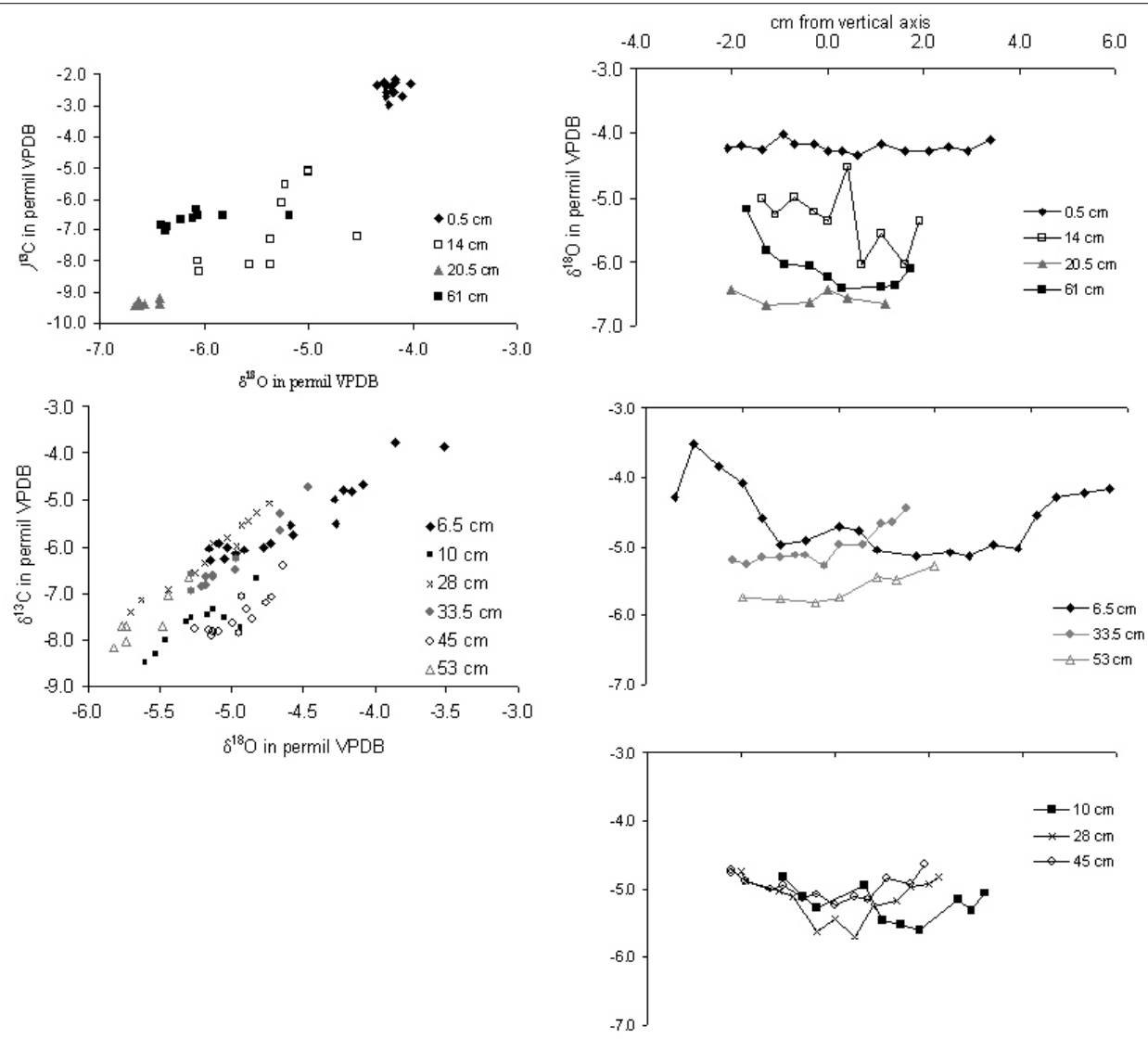

Fig. 20. "Hendy tests" at ten different heights (in cm from the top) in the PN-95-5 Père Noël stalagmite. Except at 0.5 and $20.5 \mathrm{~cm}$ from the top, the stalagmite was mostly deposited out of isotopic equilibrium as indicated by lateral $\boldsymbol{\delta}^{18} \mathrm{O}$ enrichment and covariation of $\boldsymbol{\delta}^{18} \mathrm{O}$ and $\boldsymbol{\delta}^{13} \mathrm{C}$ along single deposition layers. (Note that at $6.5 \mathrm{~cm}$, a plateau value seems to be reached around the drip impact place suggesting calcite deposition close to equilibrium at this place). 


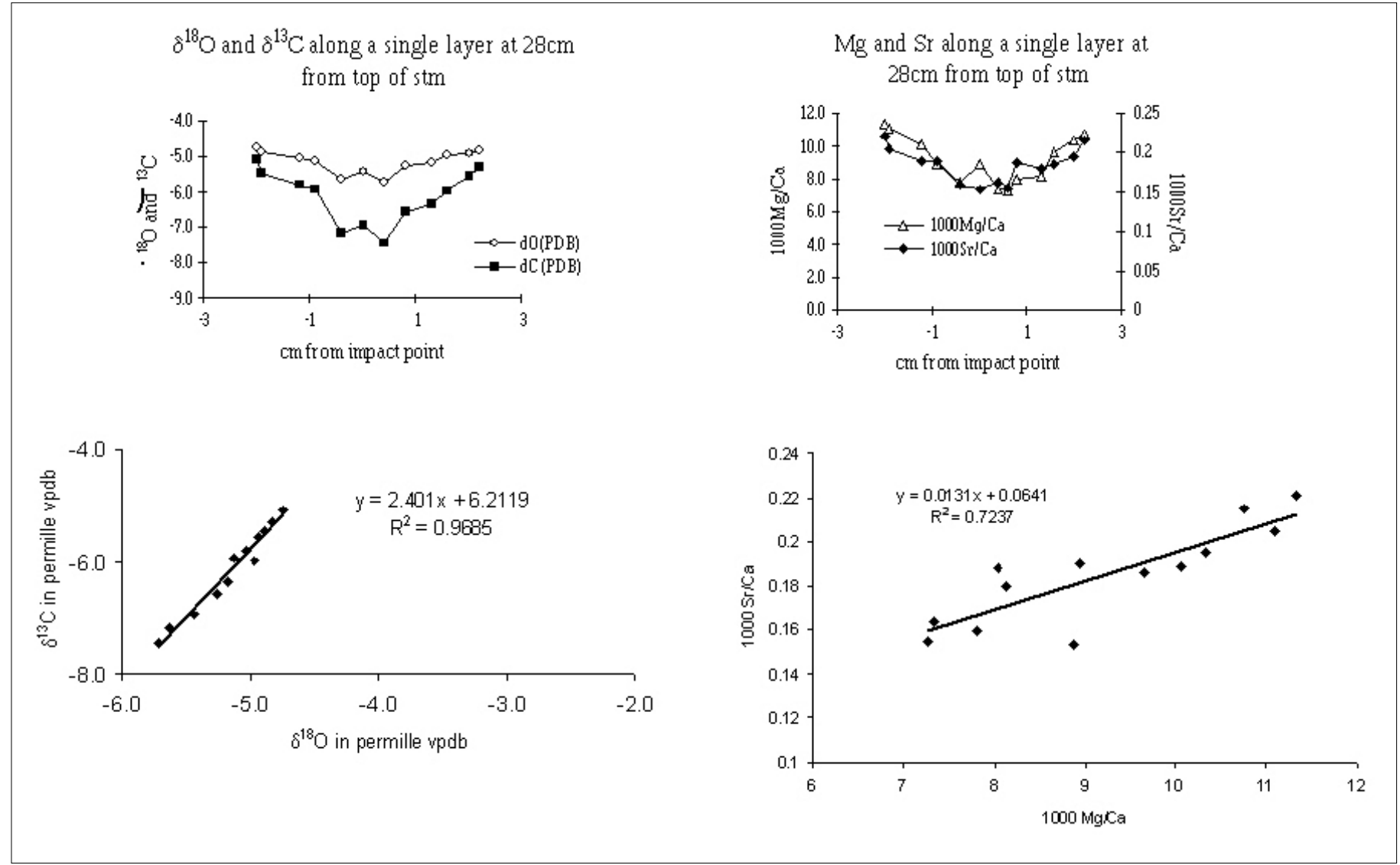

Fig. 21. Covarying trends of $\delta^{18} \mathrm{O}, \boldsymbol{\delta}^{13} \mathrm{C}, \mathrm{Mg} / \mathrm{Ca}$ and $\mathrm{Sr} / \mathrm{Ca}$ along a single layer in the Holocene Père Noël stalagmite.

of the calcite deposited in the Père Noël cave is clearly not deposited in isotopic equilibrium but, nevertheless, may give information on water availability through possible relationships between i) water recharge, drip rate and $\delta^{18} \mathrm{O}$ and $\delta^{13} \mathrm{C}$ of the cave calcite and ii) recharge, residence time, prior calcite precipitation and $\mathrm{Mg} / \mathrm{Ca}$ and $\mathrm{Sr} / \mathrm{Ca}$ composition of the water and of the precipitated calcite. The similar patterns found in $\delta^{18} \mathrm{O}, \delta^{13} \mathrm{C}$, $\mathrm{Mg} / \mathrm{Ca}$ and $\mathrm{Sr} / \mathrm{Ca}$ along a single layer in a Holocene stalagmite as well as along its longitudinal axis suggest a possible overall control of kinetics during the precipitation at the stalagmite place.

\section{ACKNOWLEDGEMENTS}

Part of the study in the Père Noël cave was financed by the EC project "Holocene/Late-Pleistocene high resolution climate reconstruction from continental carbonates (speleothems). - EV5V-CT94-0509" and by the Fund for Scientific Research Flanders (FWO). The authors would like to thank the Caves of Han for the friendly access to the cave.

\section{REFERENCES}

Alley R.B, Mayewski P.A., Sowers T, Stuiver M., Taylor K.C. \& Clark P.U., 1997 - Holocene climate instability: a prominent wide-spread event 8200 yr. ago. Geology, 25 (6): 483-486.

Craig H., 1965 - The measurement of oxygen isotope palaeotemperatures. In: Tongiorgi E. (Ed.), Stable isotopes in oceanographic studies and palaeotemperatures, Consiglio Nationale delle Ricerche Laboratorio di Geologia Nucleare, Pisa: 166-182.
Craig H., Gordon L.J. \& Horibe Y., 1963 - Isotopic exchange effects in the evaporation of water. Low-temperature experimental results. Journal of Geophysical Research, 68 (17): 5079-5087.

Dansgaard W., 1964 - Stable isotopes in precipitation. Tellus, 16: 436-468.

Delvaux de Fenffe D., 1985 - Géologie et Tectonique du parc de Lesse et Lomme au bord sud du Bassin de Dinant (Rochefort, Belgique). Bull. de la Soc. belge de Géologie, 94 (1): 81-95.

Deflandre G., Bastin B., QuinifY. \& Gewelt M., 1987 - Lagrotte du Père Noël. Colloque International de Sédimentologie karstique, Livret Guide des Excursions: 37-44.

Ek C., 1979 - Variations saisonnières des teneurs en $\mathrm{CO}_{2}$ d'une grotte belge: le trou Joney à Comblain au Pont. Annales de la Société Géologique de Belgique, 102 : 7175.

Epstein S. \& Mayeda T.K., 1953 - Variations of the ${ }^{18} \mathrm{O} /{ }^{16} \mathrm{O}$ ratio in natural waters. Geochimica et Cosmochimica Acta, 4: 213-224.

Fairchild I.J., Borsato A., Tooth A.F., Frisia S., Hawkesworth C.J., Huang Y, McDermott F. \& Spiro B., 2000 - Controls on trace element ( $\mathrm{Sr}-\mathrm{Mg}$ ) compositions of carbonate cave waters: implications for speleothem climatic records. Chemical Geology, 166: 255-269.

Fornaca-Rinaldi G., Panichi C. \& Tongiorgi E., 1968 - Some causes of the variation of the isotopic composition of carbon and oxygen in cave concretions. Earth and Planetary Science Letters, 4: 321-324.

Genty D. \& Deflandre G., 1998 - Drip flow variations under a stalactite of the Père Noël cave (Belgium). Evidence of seasonal variations and air pressure contraints. Journal of Hydrology, 211: 208-232. 
Genty D., Blamart D., Ghaleb B., Plagnes V., Causse Ch., Bakalowicz M., Zouari K., Chkir N., Hellstrom J., Wainer K. \& Bourges F., 2006. - Timing and dynamics of the last deglaciation from European and North African $\delta^{13} \mathrm{C}$ stalagmite profiles - comparison with Chinese and South Hemisphere stalagmites. Quaternary Science Reviews, 25: $2118-2142$.

Gewelt M. \& Ek C.,1986 - L'Evolution saisonnière de la teneur en $\mathrm{CO}_{2}$ de l'air de deux grottes belges: SainteAnne et brialmont, Tilff. In: Patterson K. \& Sweeting M.M. (Eds), New Directions in Karst, Proceedings of the AngloFrench Karst Symposium, Geobooks, Norwich: 49-72.

Gonzales L.A. \& Lohmann K.C., 1988 - Controls on mineralogy and composition of spelean cabonates: Carlsbad caverns, New Mexico. In: James N.P. \& Choquette P.W. (Eds.), Paleokarst, Springer-Verlag N.Y.: 81-101.

Hendy C. H., 1971 - The isotopic geochemistry of speleothems - I. The calculation of the effects of different modes of formation on the isotopic composition of speleothems and their applicability as palaeoclimatic indicators. Geochimica et Cosmochimica Acta, 35: 801824.

Inoue H. \& Sugimura Y., 1985 - Carbon isotopic fractionation during the $\mathrm{CO}_{2}$ exchange process between air and seawater under equilibrium and kinetic conditions. Geochimica et Cosmochimica Acta, 49: 2453-2460.

Kim S.T. \& O’Neil J.R., 1997 - Equilibrium and nonequilibrium oxygen isotope effects in synthetic carbonates. Geochimica et Cosmochimica Acta, 61(16): 3461-3475.

McCrea J.M.,1950 - On the isotopic chemistry of carbonates and paleotemperature scale. Journal of Chemical Physics, 18 (6): 849-857.
McDermott F., Schwarcz H. Rowe P.J., 2005 - Isotopes in speleothems. In: Leng M.J. (Ed.) Isotopes in palaeoenvironmental research. Springer, Dordrecht, The Netherlands : 185-225.

Quinif Y., 1977 - Essai d'étude synthétique des cavités karstiques de Belgique. Revue Belge de Géographie, 101 (1-3): 115-173.

QuinifY. \& Bastin B., 1986 - Le systéme karstique de Hansur-Lesse (Belgique). Actes $9^{\text {ième }}$ Cong. Int. Espeleol., Barcelona 1 : 147-161.

Roberts N, Smart P.L. \& Baker A., 1998 - Annual trace element variations in a Holocene speleothem. Earth and Planetary Science Letters 154: 237-246

Royal Meteorologic Institute (RMI), 1998 - Ringlaan3, B-1180 Brussels, Belgium. Lessives station, 19801998.

Rozanski K., Araguás-Araguás L. \& Gonfiantini R., 1993 - Isotopic patterns in modern global precipitation. In Swart P.K., Lohmann K. C., McKenzie J. \& Savin S. (Eds.), Climate change in continental isotopic record. Geophysical Monograph, 78: 1-36.

Vandersleyen P., 1967 - Atlas des grottes de Belgique 2. Institut Royal des Sciences Naturelles de Belgique, 70 p.

Verheyden S., Keppens E., Fairchild I.J., Mc Dermott F. \& Weis D., 2000 - Mg, Sr and Sr isotope geochemistry of a Belgian Holocene speleothem: implications for paleoclimate reconstructions. Chemical Geology, 169:131-144.

Verheyden S., 2001 - Speleothems as palaeoclimatic archives. Isotopic and geochemical study of the cave environment and its Late Quaternary records. Unpubl. PHD thesis. Vrije Universiteit Brussel, Belgium, $132 \mathrm{p}$. 